\title{
COVID-19 ja udmurdi pärimuskultuur
}

\author{
Nikolai Anisimov \\ Eesti Kirjandusmuuseumi folkloristika osakonna teadur, \\ Venemaa Teaduste Akadeemia Uurali osakonna Udmurdi Föderaalse \\ Uurmiskeskuse Udmurdi ajaloo, keele ja kirjanduse instituudi filoloogia \\ uuringute osakonna nooremteadur \\ nikolai.anisimov@folklore.ee; kyldysin@yandex.ru
}

Galina Glukhova

Udmurdi Riikliku Ülikooli udmurdi filoloogia ja soome-ugri uuringute ning ajakirjanduse instituudi udmurdi ja Venemaa rahvaste kirjanduse dotsent galant@udm.ru

\begin{abstract}
Teesid: Artiklis on vaatluse all kevadkombestik, Kaama-taguste udmurtide suvised palvused ja udmurtide pühad (suurpäev, adrapüha, lihavõtted, mälestuspäevad jne) COVID-19 tingitud karantiini ajal, samuti karantiinist ja eneseisolatsioonist ajendatud naljalaulud ja tšastuškad. Artikkel on esimene katse kirjeldada ja iseloomustada udmurdi pärimuskultuuri näitel ülemaailmse pandeemia mõjusid. Analüüsiks kasutati internetipostitusi, rajoonilehtede artikleid ja autorite vaatlusandmeid. Esitatud andmed võimaldavad hinnata udmurdi kombetalituste vormi muutumist ja inimeste adapteerumist kriisisituatsioonis. Eneseisolatsioon tekitas paljudes külaelanikes ärevust, sest pidustusi ei olnud võimalik läbi viia reaalajas ja tavapärases kohas. Internetipostitused kinnitasid, et udmurdid jagavad meelsasti pühade ettevalmistusi ja nende pidamist, nad postitavad õnnitlusi sõpradele ja sugulastele, võimaldades osa saada nii rõõmsatest kui ka kurbadest emotsioonidest. Internetisaitidele paigutatud humoristlikud udmurdi laulud ja tšastuškad aitavad hakkama saada koroonaviirusest tingitud keerulise olukorraga riigis.
\end{abstract}

Märksõnad: COVID-19, eneseisolatsioon, internet, kombestik, naljalaulud, pärimuskultuur, pühad, tšastuškad, udmurdid, virtuaalreaalsus

Koroonaviiruse põhjustatud haigusest COVID-19 tingitud keeruline epideemiline olukord maailmas seadis pärimuskultuuri teatud tingimustesse: paljuski muutus rahvalike kommete ja talituste vorm, sest inimestel tuli tänavu nende läbiviimisest loobuda (vt nt Koronavirus; Manitškin 2020; Japontsõ 2020; Amelina 2020; Prange \& Žukov 2020; Kulitšenko 2020). Teisest küljest tõi pandeemia esile kriisiületamise arhailised skeemid ja meetodid (Volodina 2020; Traditsionnaja meditsina 2020; Korovina 2020).

Koroonaviiruse nakatuspuhangu tõttu otsustas valitsus kehtestada kõigis Venemaa piirkondades alates 30. märtsist 2020 karantiini ja nõuda eneseisolatsiooni järgimist, mis tähendas, et tuli viibida kodus ja loobuda massiüritustest. 
Tuleb märkida, et enne 2020. aasta alguse sündmusi avaldasid välistegurid udmurtide pärimuskultuurile mõju pikkamööda. Karantiin ja eneseisolatsioon seadsid kultuurikandjad keerulisse olukorda: loobuda tuli juurdunud tavadest ja käitumise stereotüüpidest ning otsida kompromisse ja adapteeruda tekkinud olukorraga.

Käesolevas artiklis analüüsime udmurtide kevadiste kombetalituste toimimist pandeemia tingimustes (tavanditsükkel Быљӟььн нунал - suurpäev; rahvakalendri aasta ja kevadiste põllutööde algust märkiv Акашка - adrapüha ${ }^{1}$; тульсс кисьтон - kevadine mälestuspäev; samuti Baškortostani udmurtide suvised palvused). Valik tuleneb sellest, et just need kombetalitused ja pühad langesid Venemaal karantiiniaja kriitilisse perioodi. Artiklis antakse ülevaade ka koroonaviiruse ja eneseisolatsiooni teemaliste laulude- ja tšastuškade loomest kui ühiskonna reaktsioonist erakorralistele elusündmustele.

COVID-19 tingitud kriis põhjustas osadel informantidest rahutust, sest see võib õhutada inimesi järgmistel aastatel sootuks loobuma niigi hääbuvate kommete täitmisest. Nagu informandid märkisid, oli kollektiivne osalus ja suguvõsade konsolideerumine ohus individualismi kasuks, kuivõrd mainitud pühad eeldavad paljude inimeste osalemist, sugulaste kodude ja pühapaikade külastamist, osalemist ühissöömaajal. Näiteks on viimastel aastatel järkjärgult hääbunud lõunapoolsete udmurtide suurpäeva rituaalne ringkäik meesliini sugulaste kodudesse (вӧсьнерге). Mõnes piirkonnas on osa peresid suguvõsast eemaldunud ja lakanud selles ringkäigus osalemast. Kevadise mälestuspäeva ( пульсс кисьтон) rituaalne ringkäik oli paljudel etnograafilistel rühmadel piirkonniti täiesti kadunud juba 19. sajandi alguseks. Selle praktiseerimist võib kohata ainult üksikutes paiksetes tavades või üksikute perede puhul.

Pandeemia ajal olid keelatud ka massikogunemised, kalmistute ühiskülastused, sellest anti teada massiteabevahendite uudistesaadetes ja/või asundustes ülesriputatud teabelehtedel. Mõnes piirkonnas valvas kalmistu sissepääsu juures liikluspolitsei, väljas olid politseibrigaadid, kes jälgisid karantiininõuete täitmist. Külaelanikud pidid loobuma ka pühapaikade ühiskülastustest ja palvustel osalemisest.

Samal ajal suurenes inimeste internetiaktiivsus, eelkõige oli see täheldatav sotsiaalmeedias (nt VKontakte, Facebook, Odnoklassniki, Instagram).

Selle tõttu said uurimisallikaks kõikvõimalikud antud teemaga seotud postitused udmurtidelt sotsiaalmeedias, veebiintervjuud ja suhtlemine eri rühmadesse kuuluvate udmurtidega, samuti autorite isiklikud tähelepanekud. Kuivõrd täisväärtuslikke välitöid oli keeruline läbi viia, kasutasid autorid olemasoleva empiirilise materjali analüüsiks online meetodeid ja virtuaalse etnograafia lähenemisi (nt Markham 2004; Hine 2008; Sergejeva 2010). 
Tuleb mainida, et kättesaadavuse ja inimeste vajaduste tõttu on internet tänapäeval mõjutanud oluliselt nii linna- kui ka maaelanikke. Külaelanike puhul viis eneseisolatsioon selleni, et avalik tähtpäevade pühitsemine ja kombetalitused kandusid üle virtuaalmaailma. Et sisustada inimeste jõudeaega, leidsid külakultuurimajad ja teised kultuuriasutused, kelle ülesandeks on rahvakogunemisega seotud ürituste korraldamine, uusi formaate: näiteks kultuurispetsialistide tehtud videod sündmustest, online-kontserdid jmt. Ühest küljest inimesed eraldusid, teisest küljest sai virtuaalmaailmast eri inimrühmade ühendaja. ${ }^{2}$

\section{Udmurtide pärimuskultuur internetis ja elus}

Kõikvõimalikud internetipostitused võib tinglikult jagada mitmesse teemarühma: pidustuseks valmistumine, pidustuste läbiviimine, rituaalsed toidud, õnnitlused, kombetalitustest teavitamine. Internetis leiduvatest materjalidest ilmneb, et osa õigeusklikke udmurte kasutab oma postitustes nii kristlikku kui ka rahvalikku sümboolikat ja terminoloogiat; teistel, kes on resoluutsemad kristlased, kohtab kristluse-eelseid elemente harva või puuduvad need sootuks. Udmurdi põlisusundi järgijatel kristlikku sümboolikat ei esine. Postitused on tehtud nii udmurdi kui ka vene keeles.

Anname lühiülevaate igast teemarühmast.

\section{Pühadeks valmistumine}

Kuivõrd eneseisolatsioon andis võimaluse veeta rohkem aega kodus ja sealjuures internetis, hakkasid inimesed sotsiaalmeediasse postitama, kuidas nad pühadeks valmistuvad. Enamasti pakuti vaatamiseks fotosid oma pühadetoitudest ja kaetud lauast koos tekstiga, mis teatas kombetalituseks valmis olekust (ekraanipilt 1). Jagati ka kulitši retsepte, pilte värvitud ja/või kaunistatud munadest. Üks postitus sisaldas andmeid piduriiete valimisest suurpäevaks (Быљӟьли нунал) (ekraanipilt 2). Kaama-taguste udmurtide esindaja postitus Instagramis oli ajendatud kombest panna aknalauale laste jaoks uusi riideid, kingitusi ja värvitud mune, justkui oleks need suurpäevaks toonud valge habemega taat (Тӧдьь туш бабай) (ekraanipilt 3). Peale selle korraldas Udmurdimaa Malaja Purga rajooni omavalitsusüksus Bagraš-Bigra lihavõtete eel aktsiooni \#окнаПасхи (\#lihavõtteaknad), mis tähendas seda, et südaööseks tuli aknalauale panna põlev ikoonilamp (lampaad) ja foto sellest avaldada võrgustikus VKontakte vastava märksõnaga (\#окнаПасхи) (ekraanipilt 4). Korraldajate 
sõnul oli aktsiooni eesmärk anda inimestele võimalus jagada teistega lihavõtterõõmu. Ilmselgelt aitab ühistegevus leevendada ka pingeid. Olgu öeldud, et Bagraš-Bigra oli aprillis 16päevases karantiinis, sest kohalikul elanikul oli leitud COVID-19 tekitav viirus.

Ольга Перевозчикова

18 апр в 21:35 '-

Христос воскресе! Христос воскресе! Христос воскресе! Великтэмлы дась))) Нырысьсэ пыжи куличъёс))) К Пасхе готова))) Первый раз пекла куличи))) \#Пасха2020
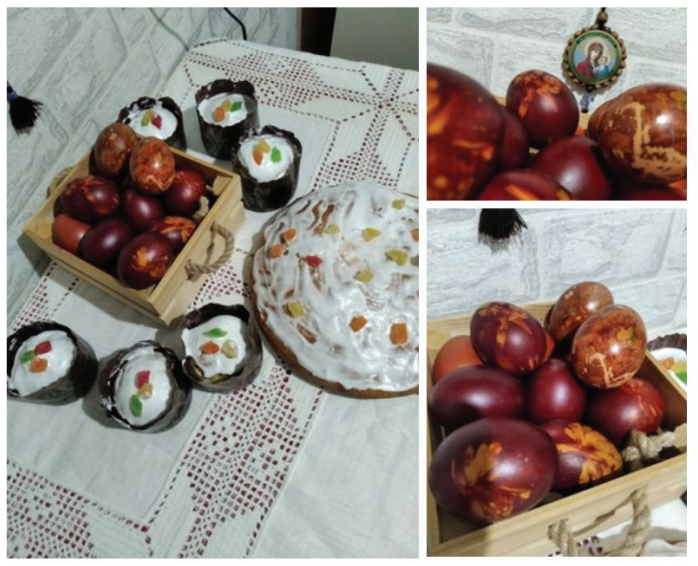

Ekraanipilt 1. https://vk.com/feed?w=wall62160647_7686, 2020.

Наталья Матвеева

18 апр в 21:52

Дорын умой, чуказе Быдз:ым нунал понна кыче меда дэремме дисялом ай малпай но. Кутски бугыръяськыны шифанерын, а отын...коня вылэм соос( может трос но овол дыр кин ке понна). Нош тиляд вань а удмурт дэремды но коня, мон чотай али, но мынам потиз 13. Весь уг на тыры ко:ты, адямиослэсь адзисько, яке басма чеберзэ син азям йо:те ке, одно вурытэме потэ.

Разбирала шкаф и оказывается у меня столько( а может и нет) национальных удмуртских платьев. А мне хочется ещё.
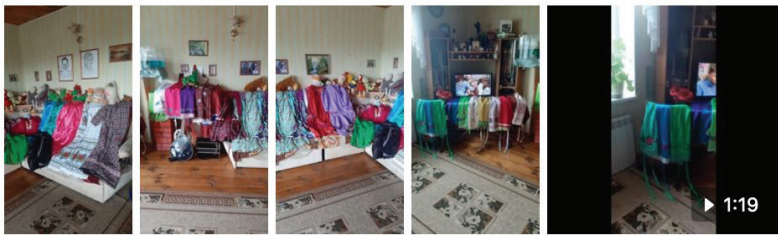

Ekraanipilt 2. https:/ / vk.com/feed?w=wall78392984_1912, 2020. 
Ekraanipilt 3. https: / / instagram.com / natiburdo?igshid=vakfekw744bk, 2020.

18 апр в 20:04

Интересная акция! Может поддержим?

- В нынешнем году из-за пандемии коронавирусной инфекции миллионы верующих вынуждены встречать Пасху дома. Люди напуганы, но мы можем исправить ситуацию. Давайте сообщим миру весть, побеждающую страх: Христос воскресе!

$\checkmark$ Сегодня в полночь зажгите масляную или неугасимую лампаду и поставьте ее на подоконник примерно на один час. Можете сфотографировать ее, а затем разместить снимок в социальных сетях, сопроводив хештегом \#окнаПасхи.

Делитесь друг с другом пасхальной радостью. Пусть все знают, что там, где Бог, всегда есть место надежде. В Евангелии сказано: «И свет во тьме светит, и тьма не объяла его».

Соблюдайте меры пожарной безопасности. Не размещайте лампады вблизи штор и легковоспламеняющихся веществ и предметов. Исключите доступ детей и домашних животных к источникам открытого огня. Не оставляйте зажженные лампады без присмотра.

Друзья, акция «Окна Пасхи» - не замена богослужения. Она не заменит пасхальный крестный ход и церковные Таинства. Цель этой акции - дать людям возможность поделиться с окружающими пасхальной радостью.

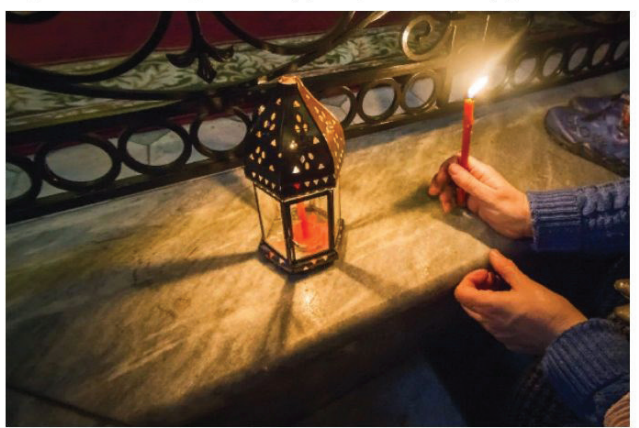

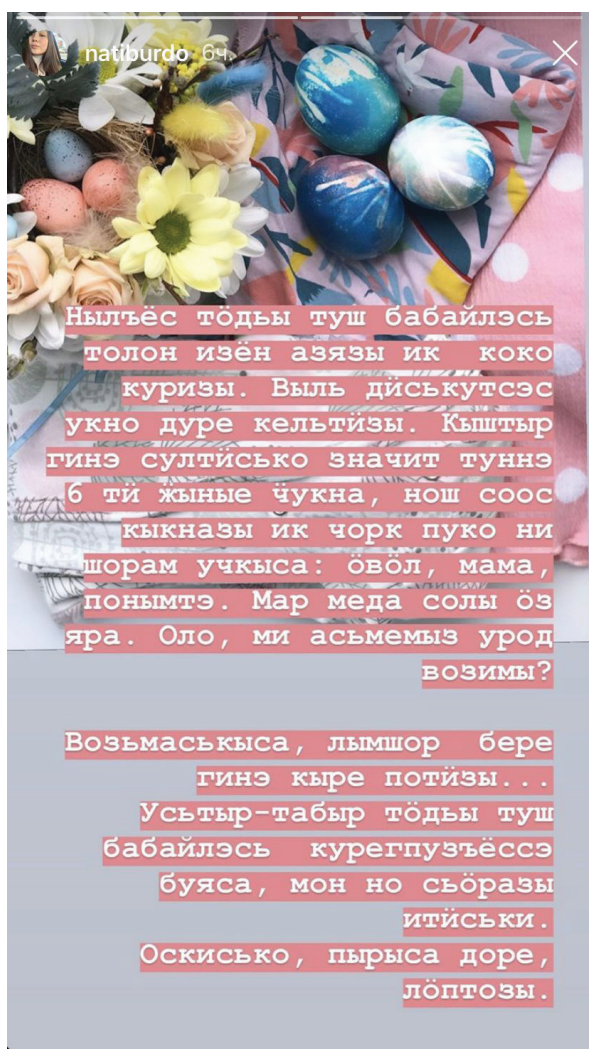

Ekraanipilt 4. https://vk.com/mobagrashbi gra? $w=w a l l-165541235 \_4326,2020$. 


\section{Pühade pidamine}

Salvestatud materjalidest nähtub, et sageli jagasid inimesed ka seda, kuidas nad kodus pühi tähistavad. Näiteks Irina Samigulova andis teada suurpäeva tähistamisest, õnnitles pühade puhul ja lisas ka foto 2020. aastast (ekraanipilt 5). Märkimist väärib, et see postitus tingis kohe Baškortostanis Burajevo rajooni Altajevo külas elava udmurdi ohvripapi Anatoli Galihhanovi vastukaja. Ohvripapp püüdis selgitada selle päeva käitumisreegleid ja rituaalseid norme. Ta kirjutas, et suurpäeval tuleb tingimata tuua allikast vett, kusjuures kaelkooku tuleb kanda ainult paremal õlal ning mingil juhul ei tohi veeanumaid maha panna. Alkoholi tohib pruukida alles pärast keskpäeva, kui on peetud perekondlik palvus ja söödud pühitsetud putru. Instagrami kasutaja Valera Sabantšin Baškortostani Tatõšlõ rajooni Malaja Balzuga külast avaldas oma isa ja poja palvepöördumise märksõnaga \#нашитрадиции (\#meietraditsioonid, ekraanipilt 5). Et eneseisolatsiooni pühade ajal kontrolli all hoida, pidid mitmed rajoonides tegutsevad riigiasutused tegema reide. Näitena võib tuua Udmurtia Alnaši rajooni kultuuriosakonna juhataja Natalia Antonova postituse (ekraanipilt 7). Nähtavasti ei suudetud siiski kõigis külades karantiinist kinni pidada. Keskkonnas VKontakte tehtud postitusest on näha, et lapsed osalesid värvitud munade ja lihavõttekingituste otsimises, kuivõrd tava on autori arvates põlvkondade-ülese tähendusega (ekraanipilt 8). VKontakte Kukmori rajooni (Tatarstan) udmurdikeelse ajalehe Vamõš (Samm) grupis viidi läbi anonüümne küsitlus, kas vastaja lapsed käisid suurpäeval väljas mune otsimas, kusjuures vastusevariante oli kolm: käisid naabrite juures, ei käinud väljas, käisid läbi terve küla. Vastustest selgus, et naabrite juures käis $22,5 \%$ (üheksa vastust), munakorjamises ei osalenud 72,5\% (29 vastust) ja kogu küla käis läbi kõigest $5 \%$ (kaks vastust). Vladimir Žukovi kommentaar, et ametnike keelust hoolimata käis tema pojaga naabrite juures mune otsimas, pälvis mõningaid negatiivseid vastukajasid. Tatarstanis Agrõzi rajooni Varkled-Bodja külas elav Natalja Matvejeva avaldas enda VKontakte kontol suurpäeva videoõnnitluse ja esitas koos oma emaga kombekohase laulu adrapüha (akaška) auks. 2017. aasta välitööde käigus salvestas Nikolai Anisimov selle laulu esitamise isaliini sugulastega peolaua taga (vt Toulouze \& Anisimov 2018: 81). Udmurdi kultuuris on tavandilaulude või nende fragmentide esitamine rituaali käigus väga oluline, see tagab edu sakraalsetes tegevustes ja müütilise maailmaruumi korrastamisel. Tõenäoliselt selle tõttu mõjus laulu esitamine muude kombetalituste ärajäämisest hoolimata päeva erilisuse tähistajana ja kombetalituse tingliku täitmisena.

Veel ühe näitena võib tuua Udmurdimaa Malaja Purga rajooni BobjaUtša küla elaniku Olga Silvestrova VKontaktesse postitatud video, kus tema ämm Maria Silvestrova (snd 1938) esitab Mõnjaki suguvõsa laulu³, mida 
lauldi lihavõtete ajal kodudes ringkäiku tehes (ekraanipilt 9). Laulu nimi viitab selle funktsionaalsele tähendusele, võib-olla just sellepärast palus minia pealesunnitud karantiinis ämmal lihavõtete ajal seda laulda. Videos on näha, et elatanud naine laulab laua taga istudes koos lastega, mis iseenesest sümboliseerib pühadelauas istumist. Kuivõrd sedalaadi laulud on haruldased ja hääbumas, toome ära laulu teksti:

Ар(ьь)лись огпол льєктылэ (й)ук Быдӟьюн нунал юондыр,

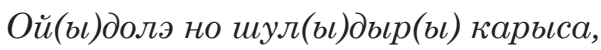
кыр(ьь)ӟаса пуколе.

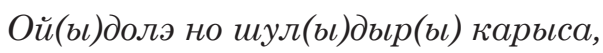
кыр(ьь)заса пуколе.

“Осто гынэ” шу(в)ильь ке, Инь(ь)лмар кабыл(ьь) мед кароз.

Кьрылм(ьь) тыюр(ьь) гынэ (й)асьлиёс, лусо гыннэ кайёсьь.

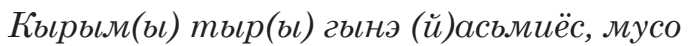
гынэ кайёсьь.

Кизььлэл но ю-няньёсль сӥзьылозь лед кисьлалоз,

Ужась гынэ адялиёсль тазалькзэс лед сётоз.

Ужась гынэ адялиёсль тазалькзэс мед сётоз.

Ой, тау улэ, тау улэ (й)ук, мусо гынэ кайёсbl,

Талэсь но бон(ьь) бадӟьнъ(ь)ёссэ

шӧдьтыса но(й) улэлэ.

Талэсь но бон(ьь) бадӟьнь(ь)ёссэ

шӧдьтыса но улэлэ.

Тау карыса (й)ул(ьь) кошкиське, нош но вуольь (й)али,

Тау карыса (й)ул(ьь) кошкиське, нош но вуольь али.
Vaid korra aastas tuleb ju püha suur päev, Rõõmustagem lauldes laulu, istugem.

Rõõmustagem lauldes laulu, istugem.

Kui vaid ütleme "Oste"4, las Inmar ${ }^{5}$ kuuleb.

Meid on vaid käputäis, mu armsad.

Meid on vaid käputäis, mu armsad.

Las meie külvatud vili sügiseni küpseb.

Tööinimestele tervist las [Jumal] kingib.

Tööinimestele tervist las [Jumal] kingib.

Oi, aitäh, aitäh teile, mu armsad,

Rohkem seda [küllust] leides elage.

Rohkem seda [küllust] leides elage.

Tänades ei lähe ära ja uuesti tuleme taas.

Tänades ei lähe ära ja uuesti tuleme taas.

(https://vk.com/id161457323?w=wall161457323_550, 2020). 
Alnaši rajooni kultuurimaja (Alnašski RDK) grupis kuulutati välja Udmurtia riikluse $^{6}$ sajandale aastapäevale pühendatud etnomaraton "Sajandi laegas" (Даур шьљьљ) märksõnadega \#культураУдлуртии (\#Udmurdikultuur), \#этоль (\#needolememeie), \#АлнашскийРДК (\#AlnašiRKM), \#сидилдола (\#istumekodus), \#100летУдмуртия (\#Udmurtia100). Projekti eesmärgiks märkisid korraldajad soovi suurendada huvi udmurdi rahva pärimuse ja vaimse kultuuri pärandi säilitamise vastu (https://vk.com/alnashiclub145006838?w= wall-145006838_2653 - 02.10.2020). Etnomaratoni esimene rubriik oli "Meie emade ja isade laulud" (Анай-атай гуръёсль). Sinna kutsuti salvestama perekonnas või külas kasutusel olnud pühadega (Быљӥьлм нунал, Акашка, вӧсьнерге) kaasnevaid tavandilaule. Postitusele oli lisatud kümme rituaalsete laulude koduvideot. Lõviosa postitajatest moodustasid Alnaši rajooni elanikud, üks video oli saadetud Baškortostani Tatõšlõ rajooni Vjazovka külast.

Artikli kirjutamise käigus saime informantidelt teated, et ühes Tatarstani udmurdi külas ei jäetud karantiinist hoolimata kevadise kalendritsükli kombestikku täitmata. Kombetäitmine kulges vastavalt väljakujunenud traditsioonile peaaegu kõigi külaelanike osavõtul. Eneseisolatsiooni tõttu ei saanud pidustustel osaleda vaid need endised külaelanikud, kes olid siirdunud elama mujale ega olnud seetõttu enam küla alalised elanikud. Otsuse pidustuste läbiviimiseks tegi külarahva enamus. Nagu naljatades ütles üks informant: "Me ju desinfitseerime ennast koroonaviiruse vastu" (anonüümne suuline teade 2020), pidades silmas alkoholitarbimist. Tuleb märkida, et traditsioon ei ole siin kunagi katkenud, isegi nõukogude ateismi ja religiooni tagakiusamise tingimustes. Enamgi veel: 19. sajandi ja 20. sajandi alguse teadlased mainisid nende udmurtide seas traditsioonide innukat järgmist ja säilitamist. Sellest tulenevalt võib mõista, miks nad valisid isegi 21 . sajandi alguse ülemaailmse pandeemia ajal oma usu ja traditsioonide järgimise.

Keerulises olukorras olid ka õigeusklikud udmurdid. Koroonaviiruse tõttu oli koguduseliikmetel ja palveränduritel keelatud külastada kirikuid (ekraanipilt 10), selle asemel soovitasid vene õigeusukiriku esindajad jälgida jumalateenistuse otseülekannet. Peale selle põhjustas kogu maailma puudutanud COVID-19 seotud ohtlik olukord ärevust seoses õnnistatud tulega Jeruusalemmas. Räägiti, et see tuli ei lasku maa peale ning see tähendab lõpuaegade algust. Peaaegu kõik massiteabevahendid, blogijad ja internetikasutajad rääkisid maailmalõpu saabumise võimalikkusest, mis tekitas rahva seas veel suuremat paanikat ja ärevust. Pühakodades viidi jumalateenistusi siiski läbi, kuid piiratud arvu inimeste osalusel: vaimulikud, lauljad, abilised. Nii võisid Udmurtia Iževski koguduses lauljad külastada pühakoda ja osaleda jumalateenistustel (Irina Ptšelovodova suuline teade 2020). Sel moel viidi pühakodades läbi jumalateenistusi ning neid kanti üle televisioonis ja sotsiaalmeedias. Näiteks väärtustas Galina 
Šušakova oma postituses udmurdikeelset jumalateenistust, tänades preestreid, isa Pavelit ja isa Mihhaili, samuti lauljaid (ekraanipilt 11). Lihavõtete jumalateenistuse ajal seisid mõned kodus televiisori ees, süütasid küünlad ja palvetasid. Täpselt nagu kirikus teenistuse ajal. Teised pidasid nõu vaimulikega ja sõltuvalt oma olukorrast palvetasid üksi või koos perega. Paljud palusid palvetes kaitset ähvardava ohu eest. Kuid nagu märgivad informandid, ei toonud need pealesunnitud tingimused rõõmu ega lasknud tunda lihavõtete tähistamise pidulikkust. See võis olla tingitud asjaolust, et puudu jäi pühal osalemise kollektiivsus, puudus vaimse ühtsuse tunnetamine tähtsal sündmusel, ei olnud võimalik minna pühalikkuse koondumise keskusse pühakotta jmt. Päevi enne ja pärast lihavõttepühi loetakse õigeusus suurteks päevadeks, seepärast on ka nende päevade jumalateenistustel osalemine koguduseliikmete silmis eriline. Pühakodade külastamise keelu tõttu otsisid paljud udmurdid võimalust anda üle kirjakesi tervise ja meelerahu taotlemiseks, et vaimulikud neid liturgia käigus ette loeksid: näiteks kes tundis isiklikult isa Pavelit, helistas otse talle, teised kasutasid lauljate vahendust. Tervikuna on udmurdi jumalateenistuste eripäral palju ühisjooni tseremoniaalsete kogemustega Venemaa teistes piirkondades (vt nt Soldatov 2020; Kuznetsova 2020; Radchenko 2020).

Erakorralistes tingimustes möödus ka kevadise mälestuspäeva (

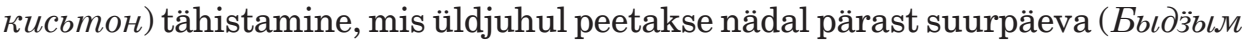
нунал). Kevadiste mälestuspäevade raames külastatakse ka 9. mail kalmistut. Algselt mälestati sel päeval Suures Isamaasõjas langenuid, hiljem muutus see kõigi lahkunute mälestamise päevaks. Nagu lihavõtete pühitsemise ajal, ei lubatud ka mälestuspäevi läbi viia ega kalmistuid külastada suurte rahvamasside osalusel. Mõnes piirkonnas, kus on veel kombeks külastada sugulaste kodusid, viidi kevadised mälestamised läbi vaid kõige lähemate sugulaste ringis (ekraanipilt 12). Teisel juhul viidi mälestuspäev läbi pereringis. Informantide sõnul tekkis ühes Baškortostani rajoonis teatav paradoks: vaatamata koroonast tulenenud keeldudele oli laupäevakul ette nähtud kohalike kalmistute koristamine. Osa elanikkonnast järgis eneseisolatsiooni ettekirjutusi ja veetis mälestuspäeva kitsas pereringis ega külastanud lahkunute kalme. Kuid informantide sõnul osales suurem osa inimestest siiski traditsioonilisel kalmistukülastusel. "Kalmistul oli nagu sabantui," märkis üks informant (anonüümne suuline teade 2020). Mõnel juhul eirati ettevaatusabinõusid ja isikliku kontakti vältimise nõuet: näiteks kostitati üksteist traditsiooni kohaselt ühisest pitsist, paljudel ei olnud maske (anonüümne suuline teade 2020). Samuti sõitsid kevadisteks mälestuspäevadeks ja 9. maiks kohale teistesse rajoonidesse ja linnadesse siirdunud külaelanikud, et külastada oma lahkunud esivanemaid. Siinkohal tuleb märkida, et mõnel pool (nt Iževskis) ei olnud selleks ajaks enam karme nõudeid ega karme kalmistu külastamise keelde, kuid nakkusoht püsis. Koos 
lahkunute mälestamisega palusid inimesed kaitset pandeemia levimise eest. Enamgi veel. Nagu teatasid informandid, kogunes ühes Udmurtia rajoonis matustele üsna palju inimesi, ühel juhul saadeti viimsele teekonnale lahkunud naist, teisel juhul meest. Ükski matustel osalenutest ei tunnetanud tõsist haigestumise ohtu, traditsioon osutus tugevamaks kui äsjakehtestatud käitumisreeglid. Toodud näited viitavad erilisele suhtumisele lahkunud sugulastesse, samuti kindlat usku nende abisse ja soosingusse. Informantide sõnul peetakse kevadisi mälestamisi ja 9. maid surnute pühaks, seepärast ootavad nad oma elusolevaid sugulasi. Arvatakse, et kõige lihtsamate kombetalituste eiramine (surnud sugulaste haudade mittekülastamine või nende mittemälestamine) võib kaasa tuua mitmeid ebameeldivusi.

Сегодня у закамских удмуртов «Быдӟынал» (Великий день), совпадающий по срокам с православной Пасхой. Заранее иду за родниковой водой.Ведь и каша и чай должны быть приготовлены на родниковой воде. В обед начинаю варить ритуальную кашу на мясном бульоне. После обеда приготовления заканчиваются, и на стол стелю белую скатерть, кладу специально испеченный в этот день хлеб, ставлю солонку с солью, миску крашеных яиц, кумышку, табани и кашу.

Счастья, мира, благополучия, здоровья любимым детям и семье , близким и друзьям, родственникам, пусть у всех все будет хорошо! Мира и добра Всем!

Быдӟынал праздникен ваньдэс но! Сюлмысь куриськыса жук сиимы.

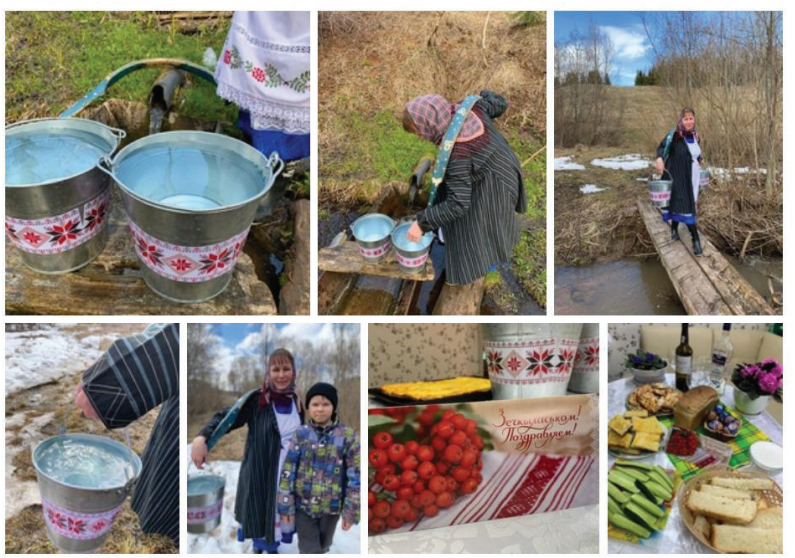

Ekraanipilt 5. https: / / vk.com / feed? $w=$ wall22919365_12005, 2020. 
Ekraanipilt 6 (paremal). https: / / instagram. com/valera.sabanchin?igshid=1prluiaho9jcu, 2020 .

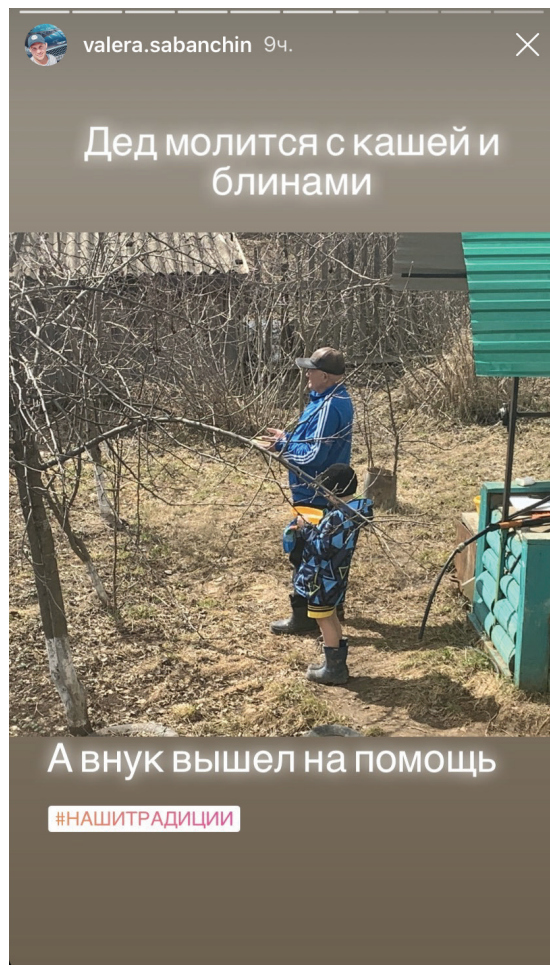

Недавно пришла домой с рейда (в рамках карантина). Замерзла - - . Теперь можно и побаловать себя праздничным обедом! :-) Христос воскресе всем! Будьте здоровы! Берегите друг друга!

\#СветлаяПасха

\#Оставайтесьдома

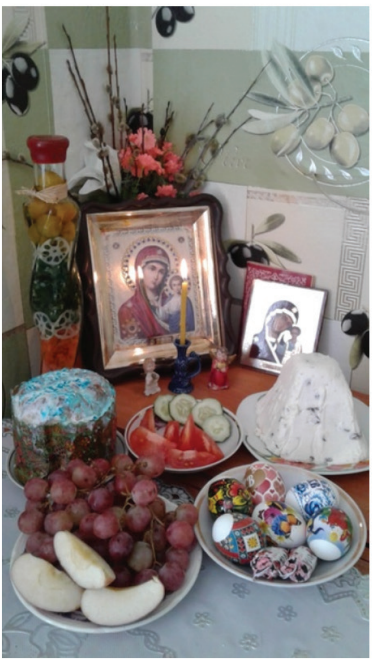

Ekraanipilt 7 (ülal).

https://vk.com/

feed? $w=w a l l 187813714 \_2144$, 2020 .

4. Алевтина Федорова

28 минут назад

А вот и наша Пасха! Когда то мы тоже ходили по домам и было очень весело и круто,в детстве очень ждали этот праздник, а теперь наши дети. И конечно же как без маминых любимых ватрушек с творогом $\Leftrightarrow$
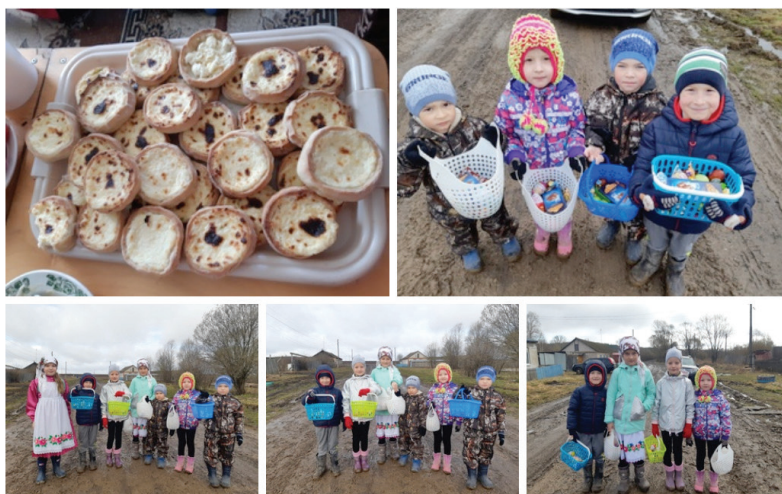

Ekraanipilt 8. https://vk.com/feed?w=wall142962886_1592, 2020 . 
Эдэйгуртысь Мыняк бо:ляклэсь Паска нерге ветлон гурзэ кырз:а Сильвестрова Мария Николаевна, 82 арес.

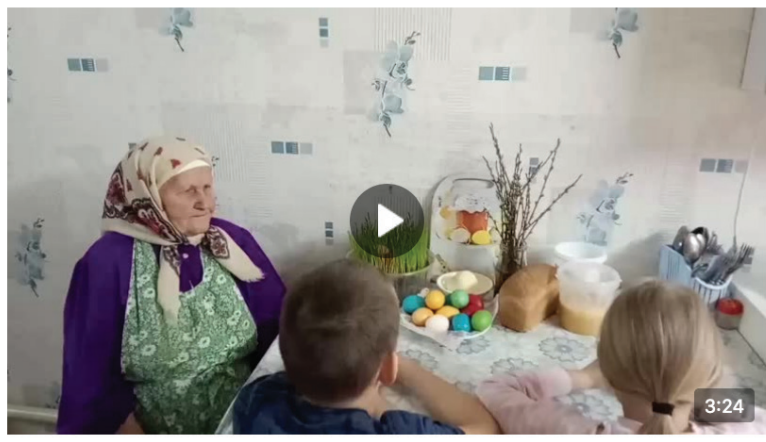

VID_20200419_122234.mp4

5363 просмотра

Ekraanipilt 9. https: / / vk.com/id161457323?w=wa ll161457323_550, 2020.

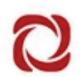

МОЯ УДМУРТИЯ. ИВОРъЁС

18 апр в 8:15 새

1..А⿵ Шаерамы черкъёсын вӧсяськисьёсты доразы пукыны куро.

17-тй оштолэзьысен коронавирус инфекциез алон вылысь черкъёсы но храмъёсы пыраны уг яра. Службаос калыктэк ортчылозы.

\#МынамУдмуртие телерадиокомпания туннэ 23 час 30 минутысен меӵак

эфирын возьматоз Ижкарысь Михайло - Архангеллэн кафедральной соборысьтыз праздниклы сйзем службаез.

Учкыны луоз Удмуртия телеканалысь но myudm.ru сайтысь. Озьы ик

чӧлскетъёс луозы мерлыко герӟетъёсмы пыр.

Уте асьтэды, матысь адямиостэс! Пуке дорады!

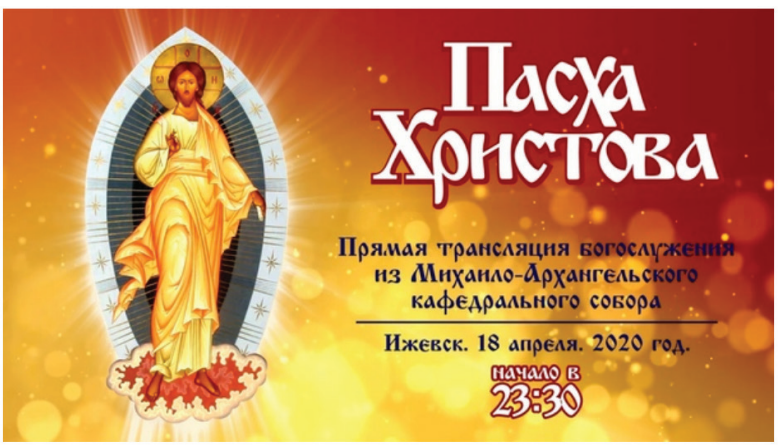

Ekraanipilt 10. https: / /vk.com/

myudm?w=wall-25185834_24314, 2020. 
Христос кулэмысь улз:ыса султи:з!Тау, Инмарлы, удмурт служба мынэ! Тау, отец Павеллы, отец Михаиллы, чирди:сьёслы!!! Тазалык Ти:ледлы_ل]

Удмурт черк/Удмуртские службы/Udmurt church

18 апр 2020 в 23:19 ㅅ․

Христос кулэмысь улз:ыса султи:з!

Христос Воскресе!
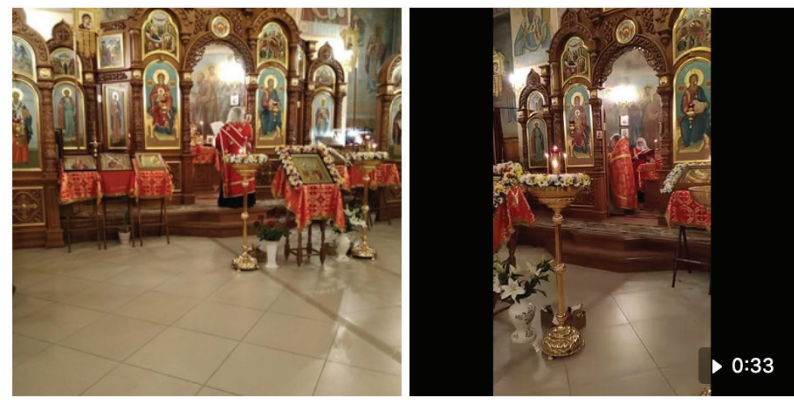

Ekraanipilt 11. https://vk.com/feed?w=wall55651469_1753,

2020.

Екатерина Шакирова

2 мая в 15:10 유

Кисьтон.

НБ, 2020.

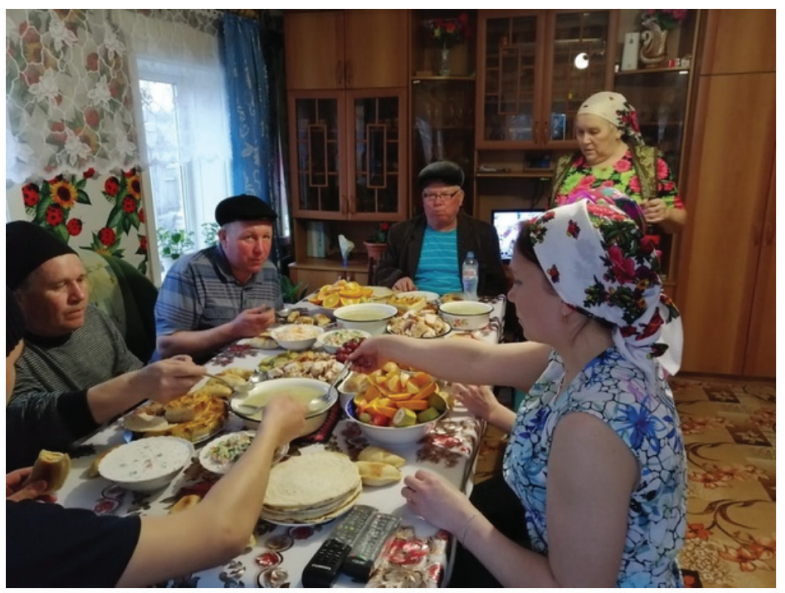

Ekraanipilt 12. https:/ / vk.com/shaislamova15? w=wa ll160459663_7557, 2020. 


\section{Õnnitlused}

Paljudes postitustes õnnitleti pühade puhul nii udmurdi kui ka vene keeles, mõnikord erinevate sisu kajastavate märksõnade all: nt \#будӟьнал, \#великтэл, \#nacxa. Mõne sisuks oli lühike õnnitlus, teistel lisandusid mitmesugused soovid, sageli sooviti tervist ja kaitset haiguste eest. Toome mõne näite.

Будйьналэн!!! Та питрес курегпуз кадь, тыр но ӥью-ӥью мед луоз улондь!!! Вань шуг секьтәёс палэнтӥ лед ортчозы коркаостэс.

Со светлой Пасхой Вас!!! Пусть ваша жизнь будет такой же здоровой, насыщеной как это праздничное яйщо!!! Пусть все несчастья и бедь обойдут Вас стороной!7 [Helgeid lihavõtteid!!! Olgu teie elu sama terve, küllastatud nagu see pühademuna!!!] (ekraanipilt 13) (https://vk.com/shonerpaul?w=wall44496167_8688 -06.10.2020).

ХРИСТОС УЛӞЫСА СУЛТЭМ! ЗЭМ НО УЛӞЫСА СУЛТЭМ! ЮГЫТ АКАШКА НУНАЛЭН ТИЛЕДЫЗ! АРМЫ КАПЧИЕН, ШУЛДЫР УЖЪЁСЫН МЕД

Павел Александров

19 anр в $15: 45$

Будӟыналэн!!! Та питрес курегпуз кадь, тыр но ӵыж-йыж мед луоз улонды!!! Вань шуг секытъёс палэнтй мед ортчозы коркаостэс.

Со светлой Пасхой Вас!!! Пусть ваша жизнь будет такой же здоровой, насыщеной как это праздничное яйцо!!! Пусть все несчастья и беды обойдут Вас стороной!

\#будӟынал

\#великтэм

\#nacxa

\#светлаяпасха

\#христосвоскрес

\#воистинувоскрес

\#shonerpaul

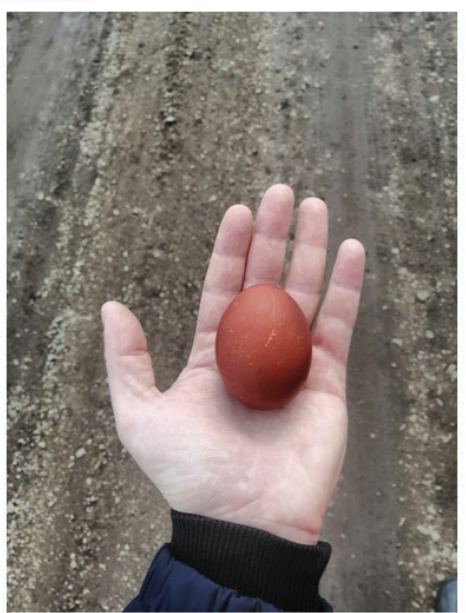

Мужской вокальный ансамбль "Валаам" - Тропарь Пасхи

Андреева Александра Ильинична 1936 г.р, ... - Айкай ( Кален... 1:50 ОРТЧОЗ! ТАЗАЛЫК, ТУПАСА УЛОН, ШУДБУР, КАНЬЫЛЛЫК МЕД ЛУОЗ КОТЬКУД КОРКАН! [Kristus on üles tõusnud. Tõepoolest tõusnud. Helget adrapäeva teile! Las meie aasta möödub kergelt ja rõõmsate töödega! Olgu tervis, üksteisemõistmine, õnn, kergus igas kodus!] (https://instagram.com/ ymia_library?igshid=torhnvtvvzlv 20.04.2020).

Ваньдэсты Быцзилм Паскаен! Котькуд сельяе мед пыроз Яратон, Тазалык, Шудбур,вань висенгес палэнэти лед кошкозы! Чагыр инбал но яркыт шунды котьку мед луоз! [Õnnitlen kõiki suure lihavõtte puhul! Tulgu Armastus, Tervis, Õnn

Ekraanipilt 13. https: / /vk.com/ shonerpaul? $w=$ wall44496167_8688, 2020. 
igasse kodusse, mingu meist kaarega mööda kõik haigused! Olgu alati sinine taevas ja ere päike!] (https://vk.com/feed?w=wall251706873_893 19.04.2020).

Ӟечкыласькол Быдӟьли нуналэн! Великтэлен! Акашкаен! Быдӥьнналэн! Сюлэльёслес мед шунтоз ӟечезль оскон! Уте асьтэды, котырысь адялиостэс, эн ьщтэ сакльктэс! Тазалыко луэ!!! [Õnnitleme suure päeva puhul! Head suurt päeva! Akaškat! Head suurt päeva! Soojendagu meie südant usk ja headus! Hoidke ennast, lähedasi, ärge kaotage ettevaatust! Olge terved!] (ekraanipilt 14) (https://vk.com/ myudm?w=wall-25185834_24321 - 06.10.2020).

Как жаль, что мой кулич не подарить, яйщо по интернету не отправить... Осталось лишь “ХРИСТОС ВОСКРЕС!" сказать и луч тепла в душе у вас оставить!!! Со светльл праздникол Пасхи, друзья! [Kui kahju, et ma ei saa kinkida oma kulitšit, interneti teel muna ei saada... Jääb üle vaid öelda "KRISTUS ON TÕUSNUD!" ja jätta teie hinge soojuskiir!!! Häid lihavõtteid, sõbrad!] (ekraanipilt 15) (https:// vk.com/id455362247?w=wall455362247_1418\%2Fall - 06.10.2020).

Югыт Пасхаен! Быљзынналэн! Ваньльз улой лед луоз! [Helgeid lihavõtteid! Head suurt päeva! Mingu kõik hästi!] (https://vk.com/ feed?w=wall10544255_2116-19.04.2020).

Зечкыласьком Акашкаен!

Чьлкььт малпаньёсын

Тырлытоли улонлес.

Ӟечезль осконэн

Юнлатол сюлэллес
Õnnitleme Akaška puhul!

Puhaste mõtetega

Täidame oma elu.

Usu ja headusega

Kinnitame oma südamed

(ekraanipilt 16) (https://vk.com/feed?w=wall128050325_1070 - 20.04.2020).

Udmurdi ohvripapp Anatoli Galihhanov avaldas oma VKontakte seinal isegi palve-tekstid: üks palve sugukonna heaks, palvele on lisatud foto suvisest palvusest pühas metsasalus; teine suurpäeva püha heaks, selle juures on tabannide $^{8}$ (kui rituaalis olulise roa) foto; samuti 1973. aastast säilinud ohvripapp Islam Armanšini palve audiosalvestis.

ШУДО БУРО МЕД ЛУОЗ БЫДӞЫНАЛМЫ!!! Тани нош улон сюрэслэсьлэсь ог ӟоззэ ортчил. Куриськельёсль Инлар Бабыкайльь доры мед вуоз. Куриськеллэс кабыл мед кароз, мед басьтоз. Олин! [Olgu meie suur päev õnnelik! Ja jälle oleme läbinud ühe osa oma eluteest. Kandugu meie palved meie vanema Inmarini. Kuulgu ja võtku vastu meie palved. Aamen!] (https://vk.com/id82757120?w=wall827571 20_1447-25.04.2020). 
Выжы понна куриськон

Югыл но мусо Инларе-Кылчинэ,
Palve sugukonna eest

Mu helge ja armas Inmar-Looja, Азьпалан улоньн лилелль Тон юрттыь! Aita meid tulevikus!

Выжылес шудбурен, зечлькен юнлаты. Meie sugu õnne ja heaga kinnita.

Кутскел ужёслес пулозяз вуттыны Alustatud tööde lõpule viimiseks Кужьллдэ но визьдэ сёть Тон, Инларе! Anna jõudu ja mõistust, mu Inmar! Янгыш сюреслэсь утьы Тон выюылес, Hoia meie sugu vale tee eest, Азвесь кенерен котырты

дыцилонлэсь.

Через”, кьлльдэез” тузонэн Тон пазьгы, Haigus ja nakkus pühi tolmuks, Андан-азвесен тазальк Тон сёты, Малык киыныц вешалля нылпилес, Югыт Шундыен шунты та улонлес! Ванен но бурен, тыр шудэн но зечен, Гид тырос пудоен, бакча ельшен, Нянен но вӧен, мушен-чечьєен, Нылььн но пиен, сельяен, туганэн, Калькен огкылысь улондэ сёты Тон, Инлиаре! Hõbedase taraga ümbritse vaenlase eest. [Justkui] terasene hõbe tervist Sa anna, Õrna käega silita meie lapsi, Heleda Päikesena soojenda meie elu! Külluse, täieliku õnne ja headusega, Täis laut karjale, juurviljaga, Leiva ja võiga, mesilaste ja meega, Tütarde ja poegadega, perega, suguvõsaga, Kooskõla rahva eluga Sa anna, Mu Inmar!

Кабыл но басьты курелмеслилесьтыли, Võta vastu meie palved, Югыт но мусо, Инларе-Кьлчинэ! Олин! Олин! Олин! Mu helge ja armas Inmar-Looja! Aamen! Aamen! Aamen!

(https://vk.com/id82757120?w=wall82757120_1440 - 25.04.2020).

Valeri Nuriahmetov avaldas VKontakte seinal koos õnnitlusega perekonna arhiivist pärit foto, millel lapsed näitavad värvitud kanamune (ekraanipilt 17). See näide demonstreerib pöördumist perekonnaalbumi kui pere ajaloo hoidja poole, samuti virtuaalset pöördumist pere poole, niiviisi saab pühade ajal avalikuks emotsionaalne ühtsus sugulastega, millest eneseisolatsiooni tõttu ilma oli jäädud.

Asutustele mõeldud õnnitlustega postitusi tegid avaliku elu tegelased, kes rõhutasid vajadust püsida kodus eneseisolatsioonis ja järgida profülaktikanõudeid. Eriline tähendus on neis postitustes illustratsioonidel ja fotodel, mille seast omakorda võiks esile tõsta foto kaetud pühadelauast ja selle vormistusest rituaalsete roogadega, erinevate pühi tähistavate atribuutidega, mis sümboliseerivad pühi (nt pajuoksad, küünal, lilled, Kaama-tagustel udmurtidel laste uus riietus; ekraanipilt 18). 
Ӟечкыласьком Быдӟым нуналэн!

Великтэмен! Акашкаен! Быдӟынналэн!

Сюлэмъёсмес мед шунтоз ӟечезлы оскон

Уте асьтэды, котырысь адямиостэс, эн ыштэ саклыктэс!

Тазалыко луэ!!!

\#МынамУдмуртие \#МояУдмуртия \#Иворъёс

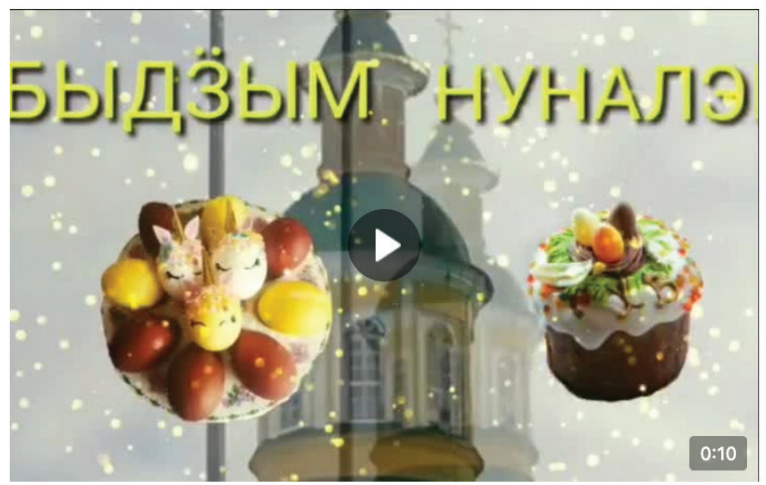

04-19-10.33.48

2239 просмотров

Ekraanipilt 14. https: / /vk.com / myudm?w=wall-25185834_24321, 2020.

Как жаль, что мой кулич не подарить, яйцо по интернету не отправить... Осталось лишь «ХРИСТОС ВОСКРЕС!» сказать и луч тепла в душе у вас оставить!!!

Со светлым праздником Пасхи, друзья!

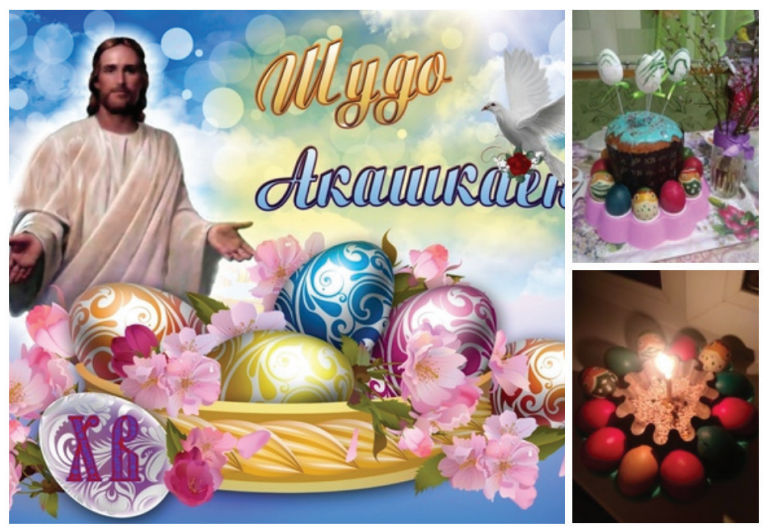

Ekraanipilt 15. https: / / vk.com/id455362247?w=wa ll455362247_1418, 2020. 


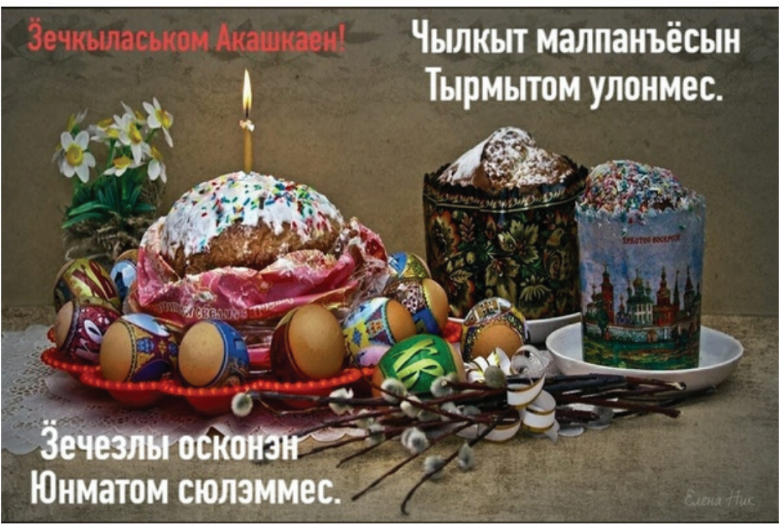

Ekraanipilt 16. https://vk.com / feed?w=wall128050325_1070, 2020 .

* БЫДӞЫМНУНАЛЭН! * Фотография из семейного альбома Нуриахметовых.

На фото: Руслан, Арина, Эльза Нуриахметовы и Дмитрий, Иван, Ирина и Алексей Тимирзяновы. А Валерий Нуриахметов (фотограф), как всегда, по эту сторону...

«Есть праздники, которые имеют свой запах. На Пасху, Троицу и на Рождество в воздухе пахнет чем-то особенным. Даже неверующие любят эти праздники. Мой брат, например, толкует, что Бога нет, а на Пасху первый бежит к заутрене..."

(А. П. Чехов, рассказ «На пути»).

https://oshmes.rbsmi.ru/articles/lulcheberet/Kitis-po..

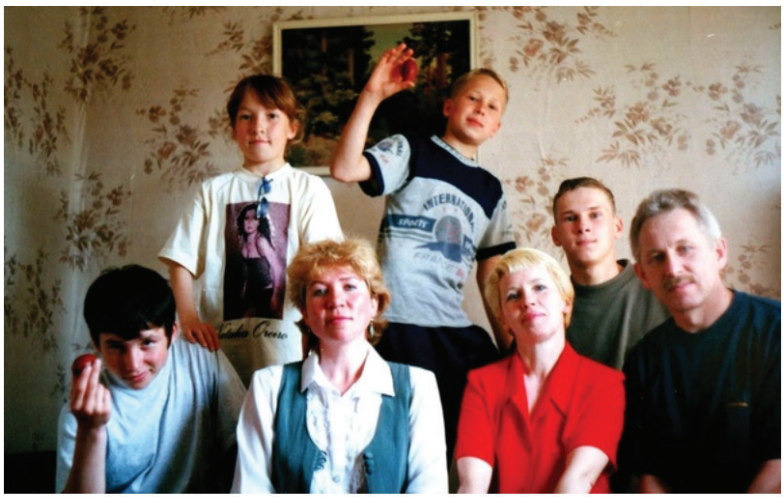

Ekraanipilt 17. https:/ / vk.com/

feed?w=wall135609259_99037, 2020. 
Новотатышлинская-Сельская Модельная-Библиотека-

Татышлински

19 апр в 20:30
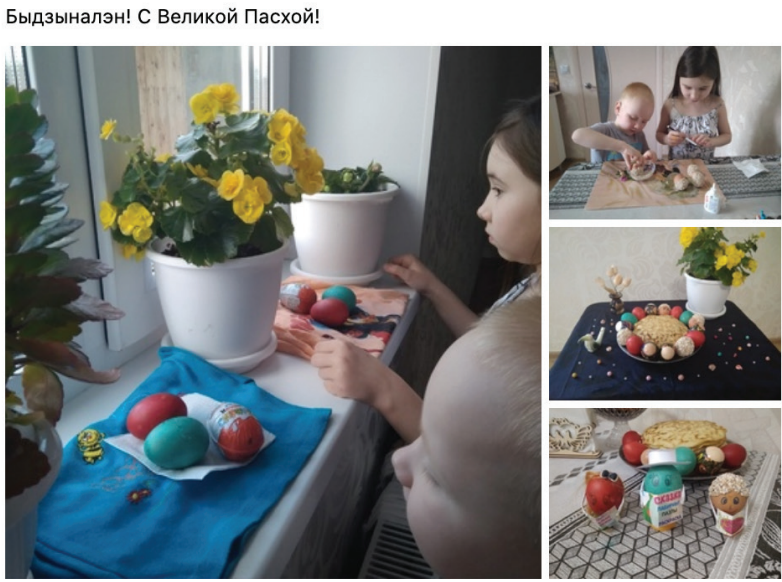

Ekraanipilt 18. https: / /vk.com /feed?w=wall262345748_1048,

2020

\section{Selgitavad teated}

Sel perioodil võis sotsiaalmeedias kohata ka postitusi selgitustega, mis tuleb teha selle või teise püha ajal, millised tegevused on soovitavad, millised keelatud, milliseid toite valmistada jmt. Näiteks kirjeldab udmurdi ohvripapp Anatoli Galihhanov VKontakte leheküljel oma postituses suurpäeva (Быљд̈̈ьннал) tähistamist. Ta kirjutab, et kõigepealt kutsusid külla sugulased, kes elasid küla selles osas, mis jäi jõe alamjooksule; ${ }^{9}$ suurpäeva ärasaatmisel (Быıдӟьннал келян) oldi külas juba sugulastel, kes elasid jõe ülemjooksu pool; kombestiku kohustuslik toit oli puder hanelihaga. Mainitud on sedagi, et mälestuspäevadel kutsutakse sugulasi kuuma suppi sööma majadesse, mis asuvad jõe ülemjooksu pool, seejärel külastatakse teiste kodusid, mis asuvad jõe alamjooksu pool. Sotsiaalvõrgustiku VKontakte Tatarstani Kukmori rajoonilehe Vamõ (Samm) grupis avaldati värvitud munadega illustreeritud väike teade tegevustest, mida sooritatakse lihavõtete ajal (suurpäev, adrapäev). Udmurdi pärimuse asjatundja, Baškortostani Tatõšlõ rajooni Aribaševo küla ohvripapi naine Lilia Garajeva avaldas udmurtide ühiskondlik-poliitilises kultuurhariduslikus ajalehes $O$ šmes (Allikas) artikli palvekäitumise reeglitest, milles kirjutas, et Kaama-taguste udmurtide traditsioonilisel suvisel mälestuspäeval ei tohi osaleda palju inimesi ning tuletas lugejatele meelde palvuses osalemise käitumisreegleid ja riietusnõudeid tseremoonia külastamise ajal (Garajeva 2020: 2). 
Азьло, Бдӟыналэ, пересьёс вань дыря, кужмазы дыря ӧтчаськиськом вал. Нырысь ӧтё шурлэн уллань палаз улись туганъёс, собере Быдӟынал келяку шурлен выллапалаз улись дорын кунояло вал. Обезательно ӟазег силен жук сиём вал. Али вань на меда сыӵеос? кылэм ӧвӧл. Нош кисььон дыря пӧсь шыд сиыны ӧтчаськоно вылланисен уллане.

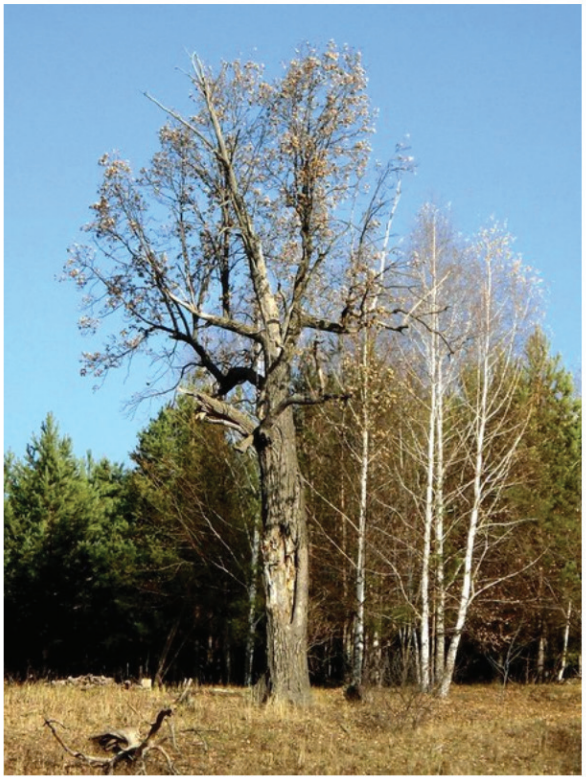

Ekraanipilt 19. https: / /vk.com/ feed? $w=$ wall82757120_1445, 2020.

Быдзымнал, Акашка (Пасха)

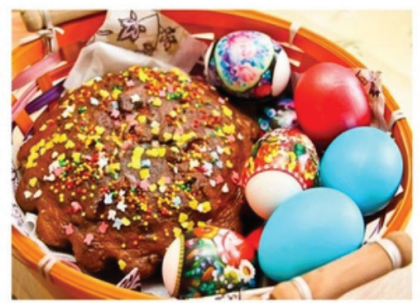

Начало нового земледельческого цикла сопровождалось обрядами изгнания Шайтана, чтобы не испортил праздника. В этот день красили яйца и складывали ихв лукошко вместе с зерном. Эти яйца вместе с зерном разбрасывали по полю и просили у бога хорошего урожая, зерен величиной с яйцо.

Ekraanipilt 20. https://vk.com/vamysh_ kukmor?w=wall-108797331_3361, 2020. 


\section{COVID-19 ja Kaama-taguste udmurtide suvised palvused}

Kaama-tagused udmurdid on ristiusustamist vältinud perifeersete udmurtide eriline etnograafiline rühm, kes tänini elab omausundis. Tänavusuvised palvused möödusid eritingimustes. Näiteks Tatõšlõ rajoonis (Baškortostan) arutati karantiini ajal võimalust korraldada palvus interneti vahendusel nagu see toimus õigeusukirikute teenistuste ajal või näiteks maride traditsiooniliste palvuste puhul (Agavairem-online 2020). Kuid udmurdi palvuste ülekannet ei toimunud. Samas rajoonis Novotatõšlõ rituaalse haru ${ }^{10}$ preestrite ja vanemate nõukogu arutas eelnevalt palvuse läbiviimise tingimusi Novotatõšlõ külanõukogu esimehega. Nad said juhised, et palvusel osalejad kannaksid maske ja järgiksid ettevaatusabinõusid. Palvuse korraldajaid informeeriti, et tseremoonia ajal võidakse läbi viia kontrollimine. Kavandati, et kombetalituses osale-

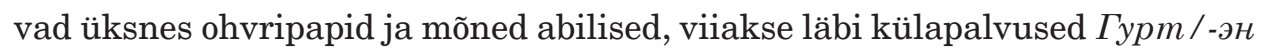
вӧcb, kuid jäetakse ära ringkonna palvus mitme ümbruskonna küla osalusel (Baidullina 2020). Vaatleme mõne näite, internetiandmetel ja veebiintervjuu põhjal mõningaid Kaama-taguste udmurtide palvuste läbiviimise iseärasusi COVID-19 tingimustes.

Tatõšlõ rajooni Urazgildõ külas (Baškortostan) viidi külapalvus (Гуртэн вӧcb) läbi neljapäeval, 4. juunil, kuigi traditsiooniliselt on palvusepäev reede. Informandid selgitasid seda asjaoluga, et palvus tuli läbi viia enne täiskuud, s.t neljapäeval, sest täiskuu langes reedele. Kaks päeva enne palvust kogusid spetsiaalselt määratud inimesed (üheksa naist) külaelanikelt palvuseks raha ja kruupe pudru jaoks, kogujate kohustuslikeks aksessuaarideks olid mask ja kindad (foto 1). Päev enne tseremooniat korraldati pühapaiga koristamine ja eelseisvaks palvuseks ettevalmistamine. Rituaal algas neljapäeval kell kaheksa hommikul. Sel aastal osalesid palvusel ohvripapp (куриськись), meesabilised ja mõned naisabilised, kes puhastasid ohvrilooma sisikonda. Pühapaiga eest hoolitseja (вӧсь кузё) jagas tseremoonial osalejatele kaitsemaskid. Nii ohvripapp kui ka tseremoonial osalejad palusid palvetes kaitset maailma vallutanud ohtliku haiguse eest. Pärast palvuse lõppu maitsesid mõned osalejad pühapaiga piirde taga samakat. Teised külaelanikud ei tohtinud pühapaigas palvusel osaleda. Oma portsu pühitsetud putru said nad alles õhtul pärast palvuse lõppu, kella 16-17 paiku. Sama päeva õhtul kogunesid igas peres kõik ühise laua taha, et pöörduda palvetes jumalate poole ja maitsta putru (anonüümne suuline teade 2020). 

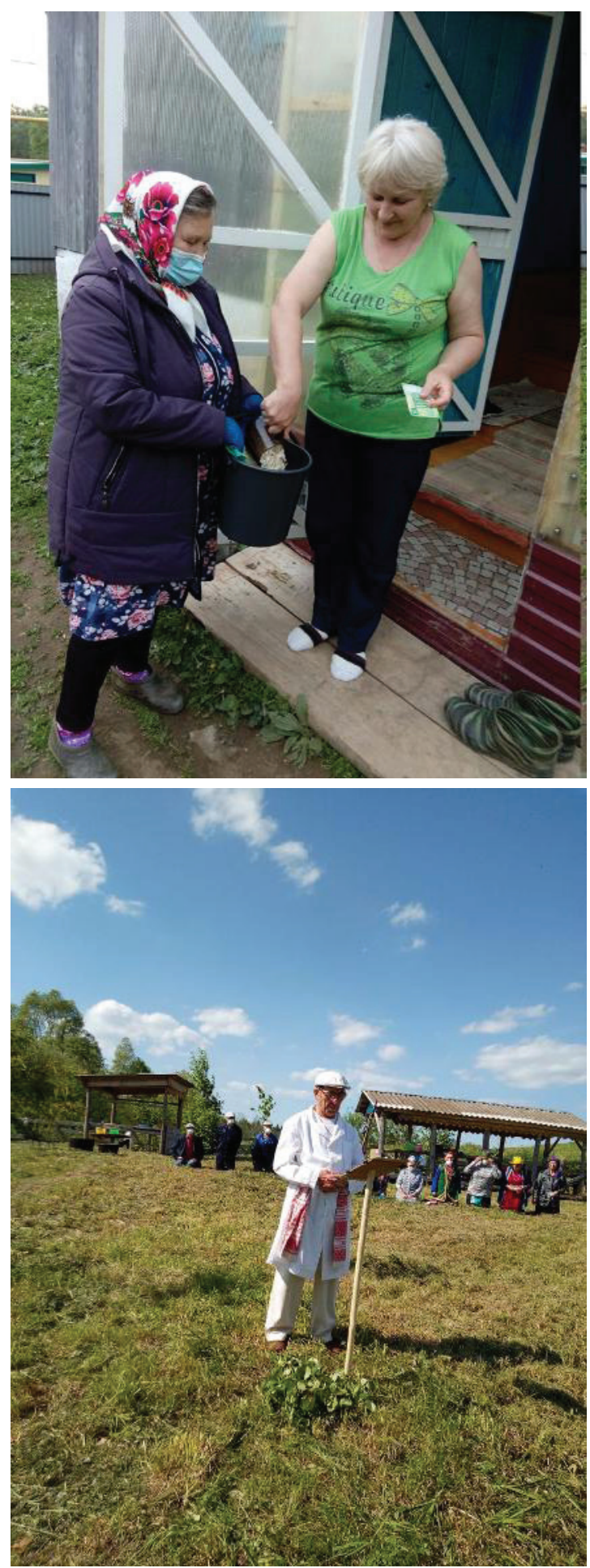

Foto 1. Palvuseks raha ja kruupide kogumine Baškortostani Tatõšlõ rajooni Urazgildõ külas. Anna Baidullina foto, 2. juuni 2020.

Foto 2. Ohvripapp Ralif Garajevi palvepöördumine Baškortostanis Tatõšlõ rajooni Urazgildõ külas. Anna Baidullina foto, 4. juuni 2020. 


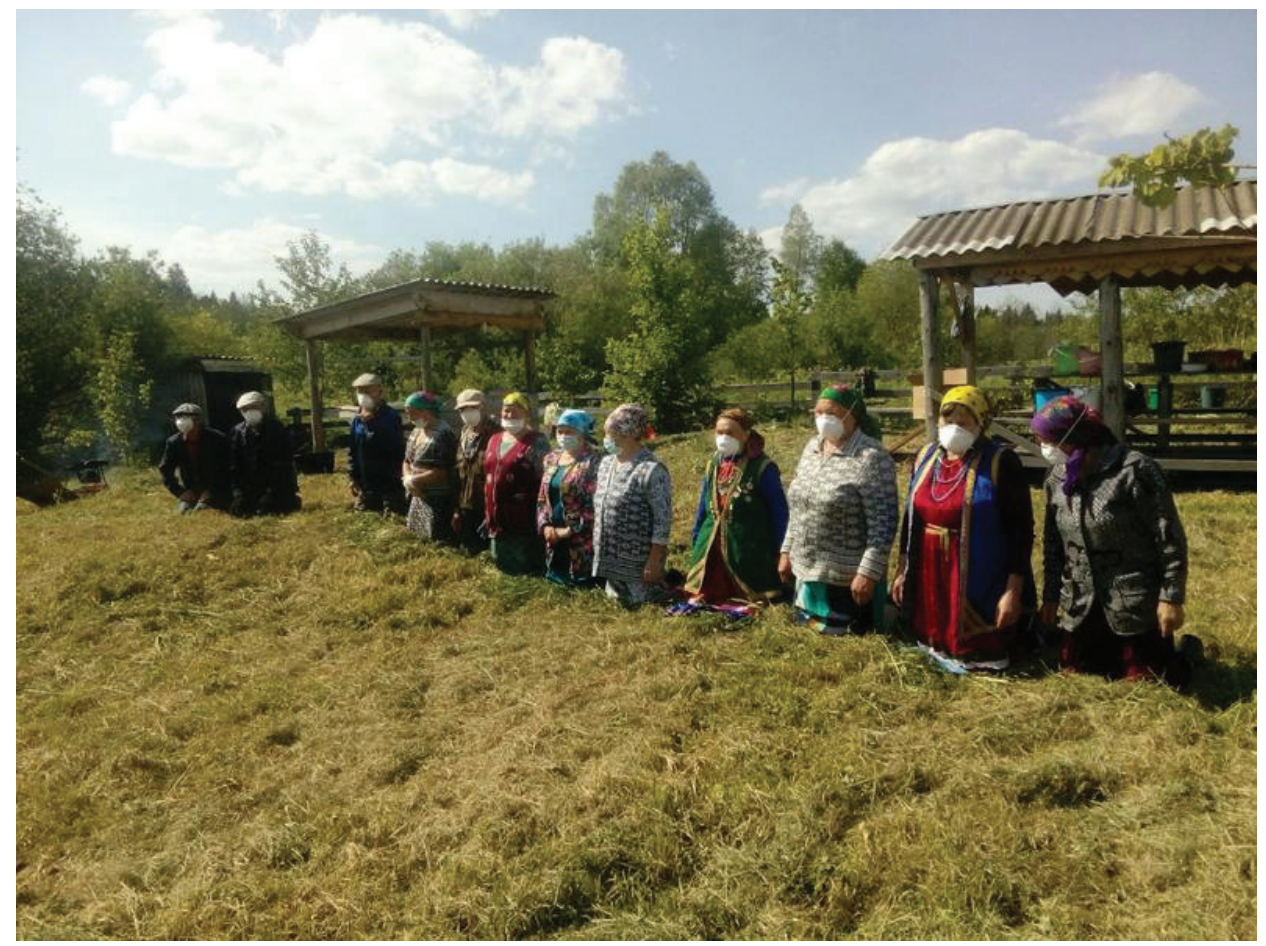

Foto 3. Palvusel osalejad Baškortostanis, Tatõšlõ rajooni Urazgildõ külas. Anna Baidullina foto, 4. juuni 2020.

Tatõšlõ rajooni Malaja Balzuga külas (Baškortostan) osalesid palvuses samuti vaid ohvripapp ja mõned abilised. Kui varem kogusid pudrukruupe lapsed, siis tänavu kogusid kruupe ja raha seitse täiskasvanud abilist. Palvus ise peeti reedel. Erinevalt eelmisest näitest võttis kohalik ohvripapp kuulda udmurdi traditsiooni asjatundjat Lilia Garajevat Aribaševo külast, tuginedes sellele, et täiskuuaeg algas alles reede ôhtul vastu laupäeva. Samamoodi toimisid ka Novõje Tatõšlõ küla ohvripapid. Pärast palvust toodi pühitsetud puder, ja seitse abilist jagasid selle külaelanikele. Eelmistel aastatel said inimesed rituaalse toidu vahetult pühapaigas (anonüümne suuline teade 2020).

Naabruses asuvas Baltatševo rajooni Asavka külas (Baškortostan) järgiti peaaegu kõiki suvise palvuse traditsioone. Ohvripapi sõnul ei saanud sel aastal läbi viia vaid palvust maajumala auks, sest külas ei olnud sobivat ohvrilooma musta karva lammast/oinast. Ohvripapi andmetel helistas ta enne palvust Tatõšlõ rajooni ohvripappidele ja konsulteeris nendega, kuidas nemad kavatsevad palvust uutes tingimustes korraldada. Nõupidamise tulemusena otsustas ta viia 
läbi kõik palvused, kuid kasutada individuaalseid kaitsevahendeid (maskid, kindad, piirituslahus). Palvust külastasid vaid need külaelanikud, kes olid selleks soovi avaldanud, peamiselt eakad inimesed. On huvitav märkida, et selles külas elavad tatarlased toetavad udmurtide palvusi, annetades selleks raha. Tänavu ohverdas mitu tatari peret rahatähti nominaalväärtusega 50 ja 100 rubla. Ohvripapp palus palves lisaks kohustuslikele palvetele ka abi ja kaitset haiguste eest, pidades silmas ka tänavust pandeemiat. Koos kahe vanemaga palvetas ta põlvili, pühitses putru, mida jagati kõigile kohalolijatele. Mees märkis, et karantiini väljakuulutamise ajal sõitis külatänavatel kohalik politseinik, kes teavitas valjuhääldi vahendusel kohalikke vanemate inimeste väljas viibimise keelust. Pärast palvuse läbiviimist avaldati Baškortostani udmurtide udmurdikeelses ajalehes Ošmes (Allikas) lühiuudis pealkirjaga "Olgu nende palved kuuldud/vastu võetud" (Вӧсяськелзы кабыл лед луоз) (Kirjanova 2020). Artiklis puudutati palvuse eripärasid, rõhutati osalejate väikest arvu ja väljendati lootust, et vaatamata kujunenud olukorrale kuuleb Inmar-Kõltšin külarahva palveid (Ibid.).

Foto 4. Palvuses osalejad Baltatševo rajooni Asavka külas (Baškortostan). Viktoria Kirjanova foto 2020.

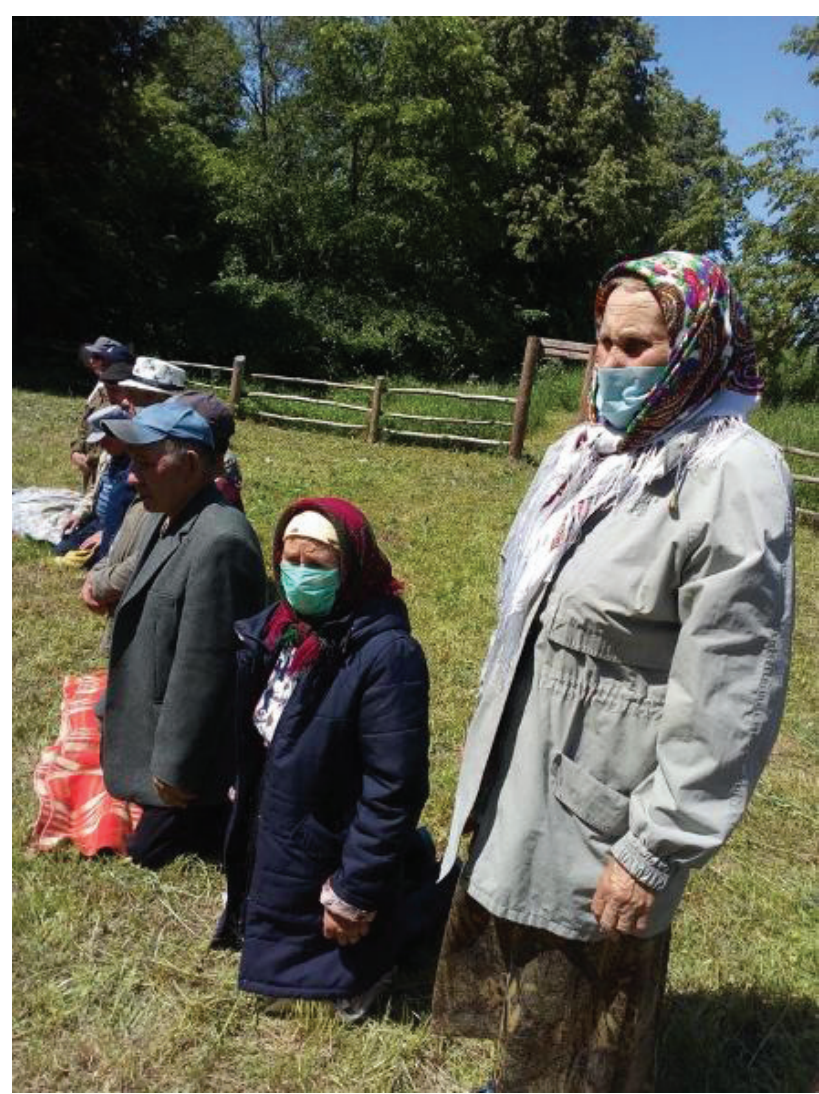




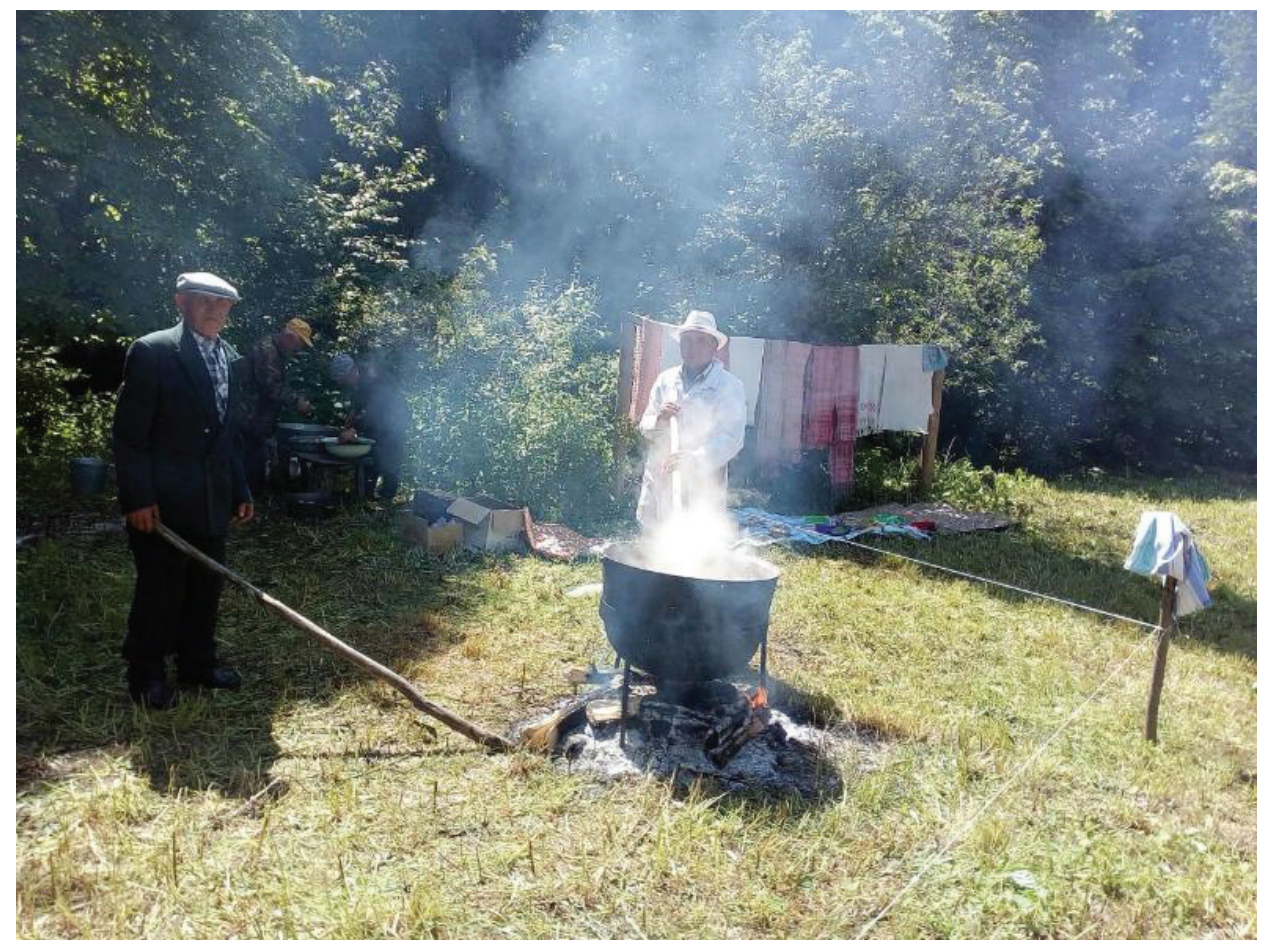

Foto 5. Rituaalse pudru valmistamine Baltatševo rajooni Asavka külas (Baškortostan). Viktoria Kirjanova foto 2020.

\section{Laulud ja tšastuškad koroonaviirusest ja eneseisolatsioonist}

Udmurdi kultuuris tekkis sel ajal ka huvitav nähtus: koroonaviiruse ja eneseisolatsiooni teemadel hakati sepitsema laule ja tšastuškasid ${ }^{11}$. On teada, et iga rahva folklooris esindavad naljalaulud lüürilist poeesiat, sellepärast on nende peamine siht mitte kirjeldada mingeid sündmusi, vaid väljendada oma suhtumist nendesse, anda edasi tundeid, mõtteid, meeleolu. Teadetest selgub, et üldjuhul on laulude tekst autori koostatud, muusika võib olla nii rahvalik kui ka autori loodud. Üldiselt oli muusikaliste tekstide koostamine sel teemal laialdane (vt nt Tšastuški ot Kuz'mitša 2020; Tšastuški pro koronavirus 2020; Itogi konkursa 2020; Italianets sotšinil 2020; Muusikavideo 2020; Kaha klip 2020). Huvitavaid näiteid õnnestus leida ka udmurdi nüüdiskultuurist. Toome ära meie käsutusse jõudnud laulude tekstid, millest paljud on humoristlikud. 


\section{Näide 1.}

Везде кипишь, везде шок,

Киттокын но тоже шок.

Та вирусэз маин виёд,

Pецептсэ кылтьсь шедьтод?

Та вирусэз маин виёд,

Pецептсэ кылтьсь шедьтод?

Урале потса учки вал,

Огкин но ӧвӧл, пайлод!

Доре прыса киме миськи,

Курыт вуэн чушиськи.

Доре прьса киме миськи,

Курыт вуэн чушиськи.

Сиса адӥел вал чеснок,

Зьныз потэ, ой, чоньдод!

Собере нош курылт вуэн

Чыртылле гылтӥ кык пол.

Собере нош курыл вуэн

Чыртылле гылтӥ кык пол.

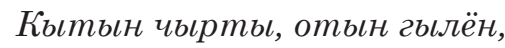

Кошкиз, кошкиз гань-гань!

Вот табере мон валай,

Айбат "дару» принилай!

Вот табере мон валай,

Айбат "дару» принимай!
Kõikjal kihad, kõikjal šokk, Ja ka Hiinas šokk.

Millega küll tappa viirust, Kus võiks leiduda retsept? Millega küll tappa viirust, Kus võiks leiduda retsept?

Läksin välja vaatama, Kedagi ei ole, ime see!

Jõudsin koju, pesin käed, Piiritusega veel kuivatasin. Jõudsin koju, pesin käed, Piiritusega veel kuivatasin.

Küüslauku süüa proovisin, Hais nüüd tahab ära tappa! Pärast jälle piiritusega Kaks korda kõri loputasin. Pärast jälle piiritusega Kaks korda kõri loputasin.

Kus on kael, seal on ka kõri, Läks ja läks nii libedalt! Alles nüüd ma taipasin, Head rohtu tuleb pruukida! Alles nüüd ma taipasin, Head rohtu tuleb pruukida!

(Anonüümne esitaja, Baškortostan, 2020).

\section{Näide 2.}

Ужтэллэсь уж луоз али -

Вина пӧзттыны пуктӥ.

Ужтэллэсь уж луоз али -

Вина пӧзттьны пуктӥ.

Гажано туган-ешвёсьн

Юны лед гожтоз али.

Гажано туган-ешгёсьн

Юны лед гожтоз али.
Igavus toob kaasa töö -

Käima panin samaka.

Igavus toob kaasa töö -

Käima panin samaka.

Austes sugulasi-sõpru

Pühad meile kätte tulgu.

Austes sugulasi-sõpru

Pühad meile kätte tulgu. 
Ай, три-дари та-тали, Вай, три-дари та-тал. Ай, три-дари та-тали, Вай, три-дари та-тал.

“Короновирус" шуысса Дорғёсаль пукиськол.

“Короновирус” шуысса Доргёсаль пукиськол. Оскисько черьёс ортчьса, Жоген чошен пулиськол. Оскисько черьёс ортчьса, Жоген чошен пулиськол.

Ай, три-дари та-тали, Вай, три-дари та-тал. Ай, три-дари та-тал, Вай, три-дари та-тал.

Тазальљк, шудбур сӥзььса, Чаркалес шуккол али. Тазальљк, шудбур сӥзььса, Чаркалес шуккол али. Пукол удлурт гур кисьтьла, Эктысса но шудысса.

Пукол удлурт гур кисьтыса, Эктысса но шудысса.

Ай, три-дари та-тали, Вай, три-дари та-тал. Ай, три-дари та-тали, Вай, три-дари та-тал.

Oй, эсьласа, эсьласа,

Сӥзььлл палэзь кисьласа.

Oй, эсьласа, эсьласа,

Сӥзььлл палэзь кисьласа.

Льктэллэ вал тӥ, ешъёсь, Чошен юол эсьласа.

Льктэллэ вал тӥ, ешъёсь, Чошен юол эсьласа.
Ai, tri-dari ta-tam, Vai, tri-dari ta-tam.

Ai, tri-dari ta-tam, Vai, tri-dari ta-tam.

Koroonaviirus öeldes nüüd, Kodudes me istume.

Koroonaviirus öeldes nüüd, Kodudes me istume.

Usun, et kui haigus läheb

Varsti kokku saame taas.

Usun, et kui haigus läheb

Varsti kokku saame taas.

Ai, tri-dari ta-tam, Vai, tri-dari ta-tam.

Ai, tri-dari ta-tam, Vai, tri-dari ta-tam.

Tervist, õnne soovides

Kokku lööme peekreid me.

Tervist, õnne soovides

Kokku lööme peekreid me.

Udmurdi viise veeretades istume, Tantsides ja mängides.

Udmurdi viise veeretades istume, Tantsides ja mängides.

Ai, tri-dari ta-tam, Vai, tri-dari ta-tam.

Ai, tri-dari ta-tam, Vai, tri-dari ta-tam.

Oh juhtuks see kas olgu või Pihlaküpsel sügisel.

Oh juhtuks see kas olgu või Pihlaküpsel sügisel.

Tuleksite, sõbrad te, Koos saaks pühi pidada. Tuleksite, sõbrad te, Koos saaks pühi pidada. 
Ай, три-дари та-тали, Вай, три-дари та-тал. Ай, три-дари та-тали, Вай, три-дари та-тал. Льктэлэ вал тӥ, ешъёсьь, Чошен юол эсьласа.

Льктэлэ вал тӥ, ешьёсь, Чошен юол эсьласа. Короновирусэз ворльса!
Ai, tri-dari ta-tam, Vai, tri-dari ta-tam. Ai, tri-dari ta-tam, Vai, tri-dari ta-tam. Tuleksite, sõbrad te, Koos saaks pühi pidada. Tuleksite, sõbrad te, Koos saaks pühi pidada. Koroonaviirust võites me!

(Esitas Irina Minliaskarova, snd 1959, Tatõšlõ rajooni Starokalmijarovo küla (Baškortostan), 2020).

\section{Näide 3.}

Мар пукиськод али дорад?

Мар карыса кьлллиськод?

“Коронавирус" шуыса,

“Коронавирус" шуьсса,

Пулиськытэк кыллиськол.

Мон азбаре потай али,

Юрт котырез тазартыныь.

Мон азбаре потай али,

Юрт котырез тазартыныь.

Курег басьтыса шашльк лэсьтӥ,

Настроениез жутынны.

Курег басьтыса шашльюк лэсьтӥ,

Настроениез жутынны.
Mis sa istud kodus?

Millega sa tegeled?

"Koroonaviirus" üteldes, "Koroonaviirus" üteldes, Elame, ei kohtu me.

Läksin mina õuele, Koduümbrust korrastama.

Läksin mina õuele, Koduümbrust korrastama.

Ostsin kanaliha, marinaadi sai šašlõkk, Tõstmaks oma meeleolu.

Ostsin kanaliha, marinaadi sai šašlõkk, Tõstmaks oma meeleolu.

(Anonüümne, Permi oblasti Tšernuška linn, 2020).

\section{Näide 4.}

Вирус вуэл Алнаше!

Вирус вуэл Алнаше,

Кальк уралььсь ьцше.

Ветло уралтии «эшьёс",

Ваньзэс улляло соос.

Вася бертьньи потэл,

Алнаш пала ни вуэл, Дугдьтэл сое патруль,
Viirus jõudis Alnašisse!

Viirus jõudis Alnašisse, Inimesed kadusid tänavalt.

Kõnnivad tänaval „sõbrad“,

Kõiki ära ajavad.

Vasja sõitis oma koju,

Alnašile lähenes,

Patrull ta kinni pidas, 
Поворачивай, пе, руль.

"Едь туда, откуда сал",

Но пырон сюрес ворсал.

"Как же так?" - шуэ Васи,

"Я же местный Ӟатча пи".

"Как же так?" - шуэ Васи,

"Я же местный Ӟатча пи.

Лэзе тӥ монэ гуртал,

Сю манет за это дам".

"Уксёдэ тон ват бордад,

Со уксен ветль в продмаг,

Ну, а маска ке кузьлад,

Может, ми лэзём гуртад."

Василэн синльљ долказ,

Дас маска бардачоказ,

"Мелэ, ваньзэ сётӥсько,

Тӥледль мон оскисько”.

Баш на баш ужа Алнаш,

Васи тот ещё торгаш,

Со тодэ таре секрет,

Кьйе иенится манет.

Со тодэ таре секрет,

Кыӥе иенится манет.

Кьззыь можно бертыныь,

Алнаше но пырыны.

Алнаше но пырыны.
Keera ümber,

"Sõida sinna kust sa tulid,"

Tee nad kinni panid.

"Kuidas nii?" on Vasja hädas,

"Ma ju kohalik, Varzi-Jatčist."

"Kuidas nii?" on Vasja hädas,

"Ma ju kohalik, Varzi-Jatčist.

Laske koju minna mul,

Annan teile sada rubla."

"Hoia raha endale,

Mine poodi sellega,

Aga kui meil maski kingid,

Võime koju lasta [sind]."

Vasja vaatab imestades,

Kümme maski bardatšokis.

"Võtke, kõik ma ära annan,

Teid ma usaldan."

Käsi peseb kätt Alnašis,

Vaat kus Vasja kauplemas,

Nüüd tal teada saladus,

Kuidas hinnatakse rubla.

Nüüd tal teada saladus,

Kuidas hinnatakse rubla.

Kuidas koju tulla saab,

Alnašisse sisse sõita.

Alnašisse sisse sõita.

(Ještšo raz pro 2020).

Järgmine näide on seotud projektiga Ektonika (nimisõnast ekton - tants) ja Vladislav Goržakiga. Projekti esindaja noorluuletaja Bogdan Anfinogenovilt pärineb udmurdi-vene tekst, Vladislav Goržak seadis Vjatka-taguste udmurtide pulmaviisi põhjal meloodia. Tulemusena valmis laulu "Minema siit, koroonaviirus" (Кош татьсь, коронавирус) salvestis ja videoklipp, milles osalesid Udmurtia tuntud inimesed ja kõik aktsioonis osaleda soovijad (Ektonika 2020). Klipile on lisatud märksõnad \#ЛучшеДома (\#paremkodus), \#ДорынУмойгес (\#kodus on parem), \#ОставайтесьДома (\#püsigekodus), \#КоронаВирус (\#koroonaviirus), \#МояУдмуртия (\#minuUdmurtia), \#Кьлљздорын (\#kuulake kodus), \#StayAtHoте, \#Удмурты (\#udmurdid), \#Удмуртия (\#Udmurtia). 


\section{Näide 5.}

Я сижу на карантине,

Я сижу на карантине,

Убираться нет уж силь,

Нет уж сильь!

Укно миськи, вью но миськи,

Оти миськи, тати миськи,

Нош ик куать час бере сиськи,

Kуать час бере!

Астэ ачид нилаз висъян, Астэ ачид нилаз висъян,

Карантин та акьльтӥз ни,

Карантин та!

Кош татысь, коронавирус,

Кош татьсь, коронавирус,

Эн ветль татӥ тон, изьвер!

$Э н$, эн ветльь!

Ой, ты, порушка-пораня,

Ой, тыл, эктоника родная,

Зачел я опять встал рано,

Очень рано!

Я за то люблю дивань,,

Ой, я за то люблю диваньи,

Поваляться с книжкой славно,

Можно славно!

Астэ ачид нилаз висъян,

Астэ ачид нилаз висъян,

Карантин та акьльтӥз ни,

Карантин та!

Кош татысь, коронавирус,

Кош татьссь, коронавирус,

Эн ветль татӥ тон, изьвер!

Эн, эн ветльь! ${ }^{12}$
Istun karantiinis,

Istun karantiinis,

Koristada pole jõudu,

Pole jõudu!

Aknad pesin, põranda pesin,

Seal ma pesin, siin ma pesin,

Jälle pärast kuut ma sõin,

Pärast kella kuut!

Eneseisolatsioon,

Eneseisolatsioon,

Karantiin on ära tüüdanud,

See karantiin!

Minema siit, koroonaviirus,

Minema siit, koroonaviirus,

Ära käi siin, metsik loom!

Ei, ära käi!

Oi, ajakene-hädakene,

Oi, Ektoonika armsake,

Miks ma jälle vara tõusin,

Väga vara!

Sellepärast armastan ma diivaneid,

Oi sellepärast armastan diivaneid,

Raamatuga lesida on mõnus,

Võib mõnuga!

Eneseisolatsioon,

Eneseisolatsioon,

Karantiin on ära tüüdanud,

See karantiin!

Minema siit, koroonaviirus,

Minema siit, koroonaviirus,

Ära käi siin, metsik loom!

Ei, ära käi! 
За продуктали я вышел, Мусор выкинул не слышно, А погодка прям по кайббу, Пря.м по кайфбу!

Ку ини чорыгало мон,

Сцена вылын кырзало но,

Одно ик вормом эшљёс ми,

Одно вормом!

Астэ ачид нимаз висъян, Астэ ачид нимаз висъян, Карантин та акыльтӥз ни, Карантин та!

Кош татысь, коронавирус,

Кош татысь, коронавирус,

Эн ветль татӥ тон, изьвер!

Эн, эн ветльь!

Массовый движ избегаю,

Массовый движ избегаю,

На балконе занилаюсь,

Я качаюсь!

На гармошке разминаюсь,

На гитаре я лабаю,

И чтобы не заразиться

Распеваюсь!

Астэ ачид нимаз висъян, Астэ ачид нимаз висъян, Карантин та акыльтӥз ни, Карантин та!

Кош татысь, коронавирус, Кош татысь, коронавирус, Эн ветль татӥ тон, изввер! Эн, эн ветльь! $!^{12}$
Toitu otsimas ma käisin, Prügi vaikselt viskasin, Aga ilm on imeline, Täitsa imeline! Millal pääsen kalale Ja laval jälle laulan ma, Me võidame kindlasti, sõbrad, Võidame!

Eneseisolatsioon, Eneseisolatsioon, Karantiin on ära tüüdanud, See karantiin!

Minema siit, koroonaviirus, Minema siit, koroonaviirus, Ära käi siin, metsik loom!

Ei, ära käi!

Massikogunemisi väldin, Massikogunemisi väldin, Rõdul võimlen, Kiigun ka, Karmoškat mängin, Kitarri sõrmitsen, Et ei nakatuks, Ma laulan!

Eneseisolatsioon, Eneseisolatsioon, Karantiin on ära tüüdanud, See karantiin!

Minema siit, koroonaviirus, Minema siit, koroonaviirus, Ära käi siin, metsik loom! Ei, ära käi!

Seda näidet eristab eelmisest laulu didaktiline funktsioon, laul levis internetis laialdaselt ja see oli ettekavandatud aktsioon. Esimesel neljal juhtumil oli initsiatiiv spontaanne ega olnud mõeldud laiemaks levitamiseks, see oli pigem inimese loominguline puhang. Nende laulude ettekannete salvestused, n-ö 
rahvasuust, ei olnud alati laiemale publikule kättesaadavad, neid jagati vaid sõpradele sotsiaalmeedias või sõnumites. Hiljem levisid need laulud sõprade vahendusel. Peamine teema on võitlus viirusega ja elu eneseisolatsioonis. Need näited on ühiskonna/loomeinimeste reaktsioon riigis ja maailmas toimuvatele erakorralistele sündmustele. Muusika keel on hea eneseväljenduse vahendaja ja psühholoogiliste pingete maandaja. Et sellised laulud on humoorikad, tekitavad nad kuulajates kõigepealt siira naeratuse või kutsuvad esile isegi naerupahvaku, mis samuti aitab leevendada pandeemiast tingitud ärevust. Sellest annavad tunnistust mitmed kommentaarid ja positiivsed vastukajad, kuigi leidub ka vastupidist: "Mis tobe laul see on?" (Что за шузи кырӟан) (Ektonika 2020).

\section{Järeldused}

Käesolev artikkel valgustas lühidalt udmurtide pärimuskultuuri kõige eredamaid ilminguid Venemaal COVID-19 tõttu väljakuulutatud karantiini ja eneseisolatsiooni tingimustes. Toodud näited ilmestasid mitmeid COVID-19 mõjusid udmurtide pärimuskultuurile, välja võib tuua mitmeid inimeste käitumist iseloomustavaid faktoreid: 1) karantiini järgimine ja rituaalide läbiviimine pereringis või väiksema hulga inimeste osalusel; 2) aktiivsus sotsiaalmeedias pühadeks valmistumise ja kombestiku täitmist kajastavate fotode ja videote postitamisel, samuti selle teemaga seotud aruteludes; 3) traditsiooniliste kommete järgimine eriolukorras mõnes külas. Siinkohal ei saa nähtavasti rääkida, nagu oleksid külaelanikud eiranud riigi korraldusi. Märkimisväärne oli kohalike võimude tegevus: üsna kiiresti ja õigel ajal võeti kasutusele kohalike elanike eneseisolatsiooni abinõud nii Udmurtias kui ka lähipiirkondades, mistõttu pandeemia ajal koroonaviirus külades levida peaaegu ei jõudnud. Võimalik, et selle tõttu ei tekkinud COVID-19 seotud olukorras külaelanike seas suurt paanikat, vaid nad viisid oma kombetalitused läbi rahulikult.

Erilist huvi pakkusid sel ajal loodud tšastuškad ja laulud, mis väljendasid inimeste reaktsiooni kujunenud olukorrale, samuti aitasid kaasa stressi maandamisele.

Massikogunemiste keeld sundis otsima suhtluseks teisi võimalusi. Seda pakkus internet. Virtuaalmaailmas ilmnes võimalus jagada sõprade, sugulaste ja lähedastega, samuti maailmaga elu pandeemia ajal. Tuleb märkida, et internetikirjed olid oluliseks allikaks mitte üksnes inimeste käitumise ja harrastuste kohta eneseisolatsioonis, vaid ka traditsioonide praeguse olukorra ja toimimise kohta kriisisituatsioonis. 
Peale selle kinnitasid andmed inimeste emotsionaalse suhtlemise olulisust, vajadust vaimse ühtsuse järele tähtpäevadel ja pühade ajal. Vaatamata rituaalsete tseremooniate asendusvariantidele ei suutnud inimesed täiel määral pühadust tunnetada ning väljendasid sellega seoses kahetsust ja kurbust. Internetipostituste kohaselt püüdsid udmurdid üksteist selles keerulises olukorras toetada. Selle heaks näiteks on toodud laulutekstid.

Praegu on raske rääkida koroonaviiruse tõsistest mõjudest udmurtide pärimuskultuurile, selleks on vaja aega ja kauem kestvaid uuringuid. Käesoleva uurimuse väärtus on selles, et see fikseeris andmed, faktid ja selle aja ilmingud, samuti inimeste teemakohased kommentaarid. See annab võimaluse edaspidi jälgida võimalikke muutusi ja kindlaks teha COVID-19 jälje udmurdi kultuuris.

\section{Tänusõnad}

Artikkel on seotud Eesti Kirjandusmuuseumi uurimisprojektiga EKM 8-2/20/3 (Folkloori narratiivsed ja uskumuslikud aspektid), selle valmimist toetas Euroopa Liit Eutoopa Regionaalarengu Fondi kaudu (Eesti-uuringute Tippkeskus, TK 145).

\section{Kommentaarid}

1 Tänapäeval on need pühad sobitatud õigeusklike lihavõtetega. Tavaliselt viiakse adrapüha läbi vahetult enne lihavõtteid, aga nn suurpäeva (Бьљӟъьн нунал) loetakse lihavõttepäevaks, seepärast tähistataksegi seda lihavõttepäeval, pühapäeval. 2020. aastal tähistati lihavõtteid 19. aprillil.

2 Et kaitsta informantide privaatsust, on allikaandmed mõnel juhul anonüümsed.

3 Suguvõsa laulude ja meloodiate esitamine on arhailine ja väga oluline komme, mida paljudes kultuurides ei esine.

4 Palves pöördumine, tähendusega "Oh Issand!"

5 Udmurdi jumaluste taevase ülemjumala nimi.

6 Nii nimetatakse Udmurdi administratiivse üksuse ehk Udmurdi autonoomia loomist 4. detsembril 1920. a.

7 Siin ja edaspidi on tekstinäidetes säilitatud originaali ortograafia ja interpunktsioon.

8 Tabann: pärmitainast pannkook.

9 Udmurdi traditsiooni kohaselt järgitakse tänini rangelt seda, millisest küla otsast, millise sugulase kodust alustatakse kodude külastamist. Kalendripühade rituaalne ringkäik kodudes algas jõe ülemjooksult (vastuvoolu); mälestuspäevade rituaalne ringkäik kodudes algas jõe alamjooksult/pärivoolu (Vladõkina \& Gluhhova 2011: 146). 
10 Tatõšlõ rajoonis eristavad uurijad kahte rituaalset rühma. Igas rühmas on oma traditsioonid ja palvuste läbiviimise eripärad, kuid koos moodustavad nad ühtse hästi funktsioneeriva süsteemi. Novotatõšlõ või udmurdi keeles Vil'gurti rühm sai oma nime rituaalse keskuse järgi, mis asub Novõje Tatõšlõ (udm Vil'gurt) külas (lähemalt vt Toulouze \& Niglas 2014: 111).

11 Päevakajalise sisuga vene rahvalaul.

12 Tekstis on säilitatud originaali interpunktsioon ja kirjaviis. Teksti andis kasutamiseks Vladislav Goržak.

\section{Allikad}

Agavairem-onlain 2020 = Agavairem-onlain: vpervye proidet priamaia transliatsiia mariiskikh molenii [mari palvuste esmakordne otseülekanne]. (https://vk.com/doc303 06561_557262847?hash=af4d0d758730cbcff3\&dl=4a6423a5ab649f2a58 -11 . oktoober 2020).

Amelina 2020 = Amelina, Mariia. Pokhorony vo vremia pandemii: kak v Minske khoroniat patsientov s COVID-19. Sputnik Belarus' (https://sptnkne.ws/Cnpk 12. oktoober 2020).

Baidullina 2020 = Baidullina, Anna. Gurten vös'es ortcho. Oshmes. (https://oshmes. rbsmi.ru/articles/oskon/Gurten-v-syos-ortcho-304791 - 12. oktoober 2020).

Ektonika 2020 = Ektonika - Brys' otsiuda, koronavirus (Kosh tatys', koronavirus) (https://youtu.be/wCzlFvjGubk - 12. oktoober 2020).

Garajaeva 2020 = Garaeva, Liliia. Vös' ortchyton esep"es. Oshmes 23 (1092), 4-tӥ invozho (iiun') 2020-tӥ ar. 2b.

Italianets sotšinil 2020 = Ital'ianets sochinil ukrainskuiu chastushku pro koronavirus (https://vk.com/video?q=\%D1\%87\%D0\%B0\%D1\%81\%D1\%82\%D1\%83\%D1\%88\%D0\%B A\%D0\%B8\%20\%D0\%BF\%D1\%80\%D0\%BE\&z=video-59719760_456240760 - 21. mai 2020).

Itogi konkursa 2020 = Itogi konkursa chastushek SAMOIZOLIATSIIA (https://vk.com/ video?q=\%D1\%87\%D0\%B0\%D1\%81\%D1\%82\%D1\%83\%D1\%88\%D0\%BA\%D0\%B8\%20 \%D0\%BF\%D1\%80\%D0\%BE\&z=video-194634011_456239404 - 21.05.2020).

Japontsõ 2020 = Iapontsy iz-za koronavirusa perestali vmeste pit' chai i sake. IA Krasnaia Vesna (https://rossaprimavera.ru/news/7a8f9956 - 12. oktoober 2020).

Ještšo raz pro... 2020 = Eshche raz pro karantin. Ispolnitel' i avtor muzyki Aleksandr Galeev, avtor slov anonim (https://vk.com/im?peers $=484005534 \&$ sel $=332254689 \& \mathrm{w}=$ wall-145006838_2469\%2F1379bf402dd1d1f43d - 21.05.2020).

Kaha klip 2020 = Kakha klip 2020 koronavirus pesnia (https://youtu.be/_S7xv6X_cPk 12. oktoober 2020).

Kirjanova 2020 = Kir'ianova, Viktoriia. Vösias'kemzy kabyl med luoz. Oshmes 24 (1093), 11-tӥ invozho (iiun'), 2020-tӥ ar. 2 b. 
Korovina 2020 = Korovina, Agata. Kak na Altae pytaiutsia dogovorit'sia s dukhom COVID-19 i spasti planetu. Interv'iu s antropologom. Intellektual'nyi zhurnal o kul'ture i obshchestve NOZh (https://knife.media/altai-covid/ - 12. oktoober 2020).

Koronavirus... = Koronavirus skazyvaetsia na traditsionnoi kul'ture v Iaponii. Nippon. com (https://www.nippon.com/ru/news/yjj2020030400535/ - 12. oktoober 2020).

Kulitšenko $2020=$ Kulichenko, Irina. Tserkov' perenesla pominal'nye dni. Инфорлационно-аналитический портал “Харьковские Извъстия» (http://izvestia. kharkov.ua/on-line/20/1303447.html - 25.05.2020).

Kuznetsova $2020=$ Kuznetsova, Irina. Traditions and Technologies: A Change in the Practice of Orthodox Worship During COVID-Pandemic: The Case of the St. Elias Church of Krasnodar (Russia). Editura Lumen (https://youtu.be/eHOmzuwSumY 3. oktoober 2020).

Muusikavideo... 2020 = Muusikavideo "Für Koroona". YouTube (https://youtu.be/ udZ7m1dumSc - 12. oktoober 2020).

Prange \& Žukov $2020=$ Prange, Astrid \& Zhukov, Evgenii. Pokhorony v usloviiakh pandemii koronavirusa: proshchanie zapreshcheno? DW (https://p.dw.com/p/3akZy 12. oktoober 2020).

Radchenko 2020 = Radchenko, Daria. Easter Online: Producing Spaces, Transgressing Borders. Editura Lumen (https://youtu.be/NZknhWPkAcQ - 12. oktoober 2020).

Soldatov 2020 = Soldatov, Aleksandr. "Pir very'vo vremia chumy. Kak proshla karantinnaia Paskha. Novaia Gazeta (https://novayagazeta.ru/articles/2020/04/19/84990-pir-veryvo-vremya-chumy - 12. oktoober 2020).

Traditsionnaja meditsina 2020 = Traditsionnaia meditsina i COVID-19: chto dumaet VOZ? Novosti OON (https://news.un.org/ru/story/2020/05/1377352 - 12. oktoober 2020).

Tšastuški ot Kuz'mitša 2020 = Chastushki ot Kuz'micha. Pro koronavirus (https:// vk.com/im?peers $=455362247 \&$ sel $=220510108 \& \mathrm{z}=$ video301522471_456239075\%2F7a 57c63fe22b4cdb97\%2Fpl_post_301522471_46 - 21. mai 2020).

Tšastuški pro koronavirus 2020 = Chastushki pro koroavirus (https://vk.com/video?q= $\% \mathrm{D} 1 \% 87 \% \mathrm{D} 0 \% \mathrm{~B} 0 \% \mathrm{D} 1 \% 81 \% \mathrm{D} 1 \% 82 \% \mathrm{D} 1 \% 83 \% \mathrm{D} 1 \% 88 \% \mathrm{D} 0 \% \mathrm{BA} \% \mathrm{D} 0 \% \mathrm{~B} 8 \% 20 \% \mathrm{D} 0 \% \mathrm{~B}$ F\%D1\%80\%D0\%BE\&z=video32627244_456242727 - 21. mai 2020).

\section{Kirjandus}

Hine, Christine 2000. Virtual Ethnography. London, Thousand Oaks, New Delhi.

Manitškin 2020 = Manichkin, Nestor 2020. Epidemicheskie ogranicheniya i opyt religioznoy obshchiny: tserkovnaya zhizn' moskovskikh katolikov vo vremya pandemii COVID-19. Meditsinskaya antropologiya i bioetika. Nauchnyi, obrazovatel'nyi, nauchnopopuliarnyi zhurnal (http://www.medanthro.ru/?page_id=4540 - 12. oktoober 2020).

Markham, Annette N. 2004. Internet Communication as a Tool for Qualitative Research. Silverman, D. (toim). Qualitative Research: Theory, Method, and Practices, 2. trükk. 
London: Sage (https://annettemarkham.com/writing/silvermangalleyproofs.pdf 3. oktoober 2020).

Sergejeva 2010 = Sergeyeva, Ol'ga 2010. Mir sotsial'nykh setey: opyt virtual'noy etnografii na materiale VKontakte. Ru. Nauka televideniya 7 (https://cyberleninka.ru/ article/n/mir-sotsialnyh-setey-opyt-virtualnoy-etnografii-na-materiale-vkontakte-ru 12. oktoober 2020).

Toulouze, Eva \& Anisimov, Nikolai 2018. “The Year Replaces the Year.” Udmurt Spring Ceremonies of the Non-Christian Udmurt: An Ethnographic Analysis of Contemporary Ritual Life (on Materials from Varkled-Böd'ya Village). Journal of Ethnology and Folkloristics 12 (1), lk 59-94 (doi: 10.2478/jef-2018-0005).

Toulouze, Eva \& Niglas, Liivo 2014. Udmurt animistic ceremonies in Bashkortostan: fieldwork ethnography. Journal of Ethnology and Folkloristics 8 (1), lk 111-120.

Vladõkina \& Gluhhova 2011 = Vladykina, Tat'iana G. \& Glukhova, Galina A. Ar-godbergan: Obriady i prazdniki udmurtskogo kalendaria. Izhevsk: izd-vo Udm. Universiteet.

Volodina, Tat'yana 2020. Pandemiya i aktualizatsiya arkhaicheskikh skhem preodoleniya krizisnoy situatsii. Meditsinskaya antropologiya i bioetika. Nauchnyi, obrazovatel'nyi, nauchno-populiarnyi zhurna]. (http://www.medanthro.ru/?page_id=4559 - 12. oktoober 2020).

\section{Summary}

\section{COVID-19 and Udmurt traditional culture}

\section{Nikolai Anisimov}

Research Fellow

Department of Folkloristics, Estonian Literary Museum, Estonia

Junior Research Fellow

Department of Philological Studies

Udmurt Institute for Research in History, Language and Literature Udmurt Federal Reseach Centre of the Ural Section,

Russian Academy of Sciences

nikolai.anisimov@folklore.ee; kyldysin@yandex.ru

\section{Galina Glukhova}

Associate Professor

Institute of Udmurt Philology, Finno-Ugric Studies and Journalism

Udmurt State University, Russia

galant@udm.ru

Keywords: COVID-19, humorous songs and chastushkas, internet posts, ritual and holidays, self-isolation, traditional culture, Udmurt, virtual space 
In this article, we examine the spring ceremonies, the Eastern Udmurt's summer ceremonies, and the Udmurt holidays (the Great Day, the Day of the Plough, Easter, commemoration days, etc.) during the COVID-19 quarantine as well as the humorous songs and chastushkas inspired by the quarantine and self-isolation. This article is the first attempt to describe and characterise the influence of the pandemic on the example of the Udmurt traditional culture. In our analysis, we rely on internet posts, data transmitted by informants, articles in district papers as well as observations by the authors. The data allow us to evaluate the changes in Udmurt customs and people's adaptation to critical situations. Self-isolation caused anxiety in many village dwellers, because it was not possible to party in real time and place. The internet posts confirmed that the Udmurt are happy to share preparations and proceedings of their feasts, they like to send congratulations to friends and kin, who are able to participate both in joyful and sad emotions. The humorous Udmurt songs and chastushkas posted on the Internet help to survive in the difficult situation in the republic due to the COVID-19 crisis.

Nikolai Anisimov (Phd) on Eesti Kirjandusmuuseumi folkloristika osakonna teadur ning Venemaa Teaduste Akadeemia Uurali osakonna Udmurdi Föderaalse Uurmiskeskuse Udmurdi ajaloo, keele ja kirjanduse instituudi filoloogia uuringute osakonna nooremteadur. Tema huviorbiidis on peamiselt udmurdi pärimus- ja nüüdiskultuur, täpsemalt udmurdi esivanematekultus ja laulutraditsioon.

Nikolai Anisimov ( $\mathrm{PhD})$ is Research Fellow at the Department of Folkloristics at the Estonian Literary Museum, Estonia, and at the Department of Philological Studies at the Udmurt Institute for Research in History, Language and Literature (UdmFRC UB RAS), Izhevsk, Russia. His main field of interest is Udmurt traditional and contemporary culture, and more precisely, the living ancestors' cult by the Udmurt and their singing tradition.

nikolai.anisimov@folklore.ee; kyldysin@yandex.ru

Galina Gluhhova (filoloogiakandidaat) on udmurdi folklorist. Ta on Udmurdi Riikliku Ülikooli udmurdi filoloogia ja soome-ugri uuringute ning ajakirjanduse instituudi udmurdi ja Venemaa rahvaste kirjanduse dotsent ning õpetab udmurdi kirjandust ja rahvaluulet. Tema peamine huvivaldkond on udmurdi ja soome-ugri folkloor, udmurdi pärimuskultuur, udmurdi folkloori ja kirjanduse koostoime.

Galina Glukhova (Candidate of Philology) is an Udmurt folklorist. She is Associate Professor at the Institute of Udmurt Philology, Finno-Ugric Studies 
and Journalism and teaches Udmurt literature and folklore. Her main field of interest is related to the research on Udmurt and Finno-Ugric folklore, Udmurt traditional culture, and the interaction of Udmurt folklore and literature.

galant@udm.ru 